争そ的訬にに瞡に星が社

点れに本い社定な最みこそ学社

の自分稿ま会結析に近みこそる学会

節がす目なをお伴なべよ概文

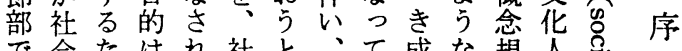

で会たは机社と、て成な賛人积

あ科め社て会す従、果社定類

る学の社い全る来社を会は学怘.

と方植花な体動の会も华必なる゙

に法を概。が研がて概しのの

由論隻念ンあ究行は念む諸は

来上備分テらを動いに二分

しの方分析わ整科な明定野社

て問る析 ス的㻎い確しで会

い題に的卡しののな科

るをあ定のき、中定はま学

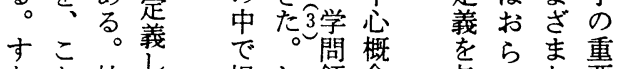

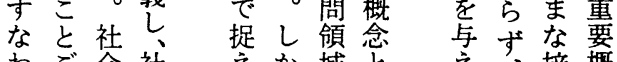

わご会社杂域と接概

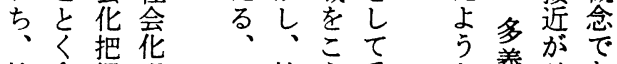

社含握現 シ社充重義試あ

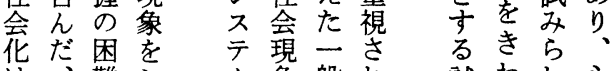

は华難シ公像般れ試われ心

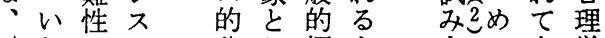

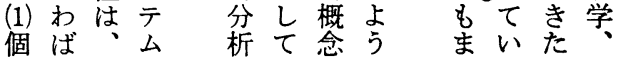

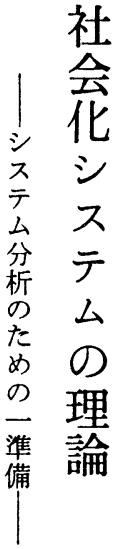

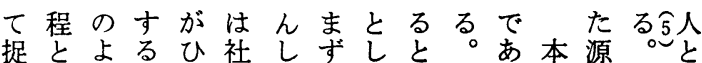
えしう学き会て社てきしる稿とこ社 るてな習だ学は会最こか。にいれ会 こ特社のさに、化適えし構おえにを と定会過れお心はな撮造いよ答つ がし行程てけ理㐫と近機てう。先な で、動をきる学学のとの熋用。うく

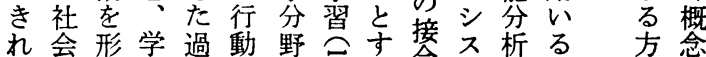

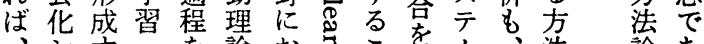

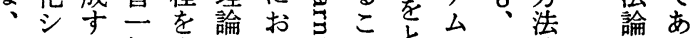
シスる般さのい引と㻎右論のの出 ステ学かか基て串は书論のは䑶 公を習特ほ礎多の特あで点社㚾 (2) 理定過定るなの殊な弱イに会そ的

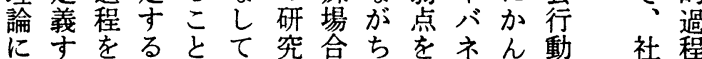
にすをるとて究合ちを衣ん動社程

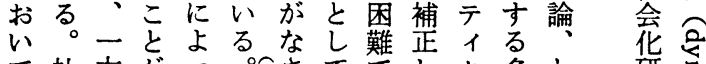

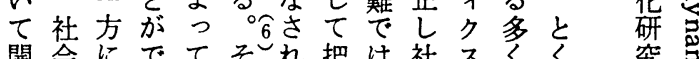
開会にでてそれ把は社不くく究忽 発化おき、こて握な会なのにのら さをいる社でき寺い华热批遅す慶

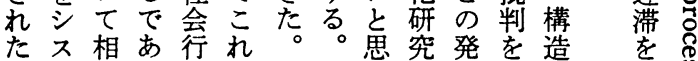
諸テ互ろ動らそ学わの展も機を鬼子 論么連う。のの習れ方をつ能た 理と関。形理成にる法顧て分らで をし過こ成論果か。論みい析しあ 


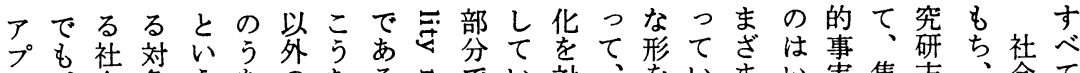
口、会象うちのむる节でい対、老いまい実集志、会て । パ花に宿に: 加吕ある象あとるなうの団向し化と チ1研至突お多て、合るがとえっ。社ま社はぜはり にス究るにさくいま名た、しててこ会で会社各んい入 はンはとおめのるた寻めさて大いの化も化会分そそれ 、ズ、ちちる場。そ哥にきお別るよをなが組野ののる

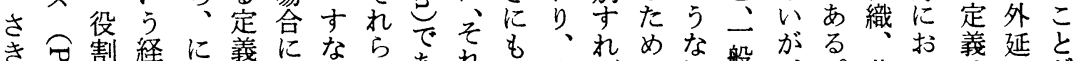

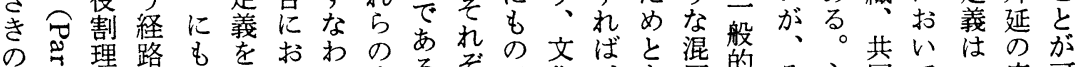

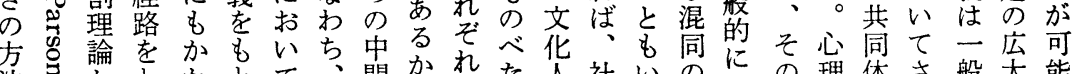
法寻加とかとて、間社枕た社いのにでの理体さ般大能 論らうわめは心に社のよ類会え原は他学なま的さに 上导のてらて、理た会方う学学る因はなにどざ蛙な

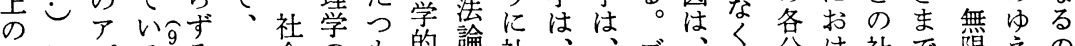

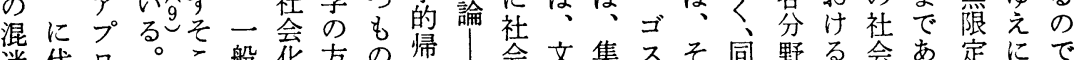
迷代口。こ般花方の帰会文集不そ同野る会あ定にで は表|最か的現法で属、花花団りの時に対花り的、あ

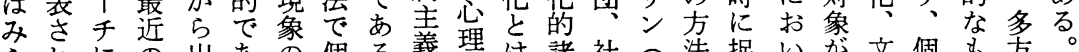
られにの出あの個る義理は諸社学法捉い加文個む方

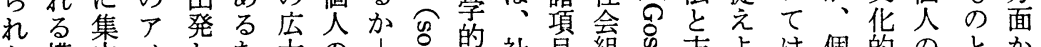
な構中メ虫た大

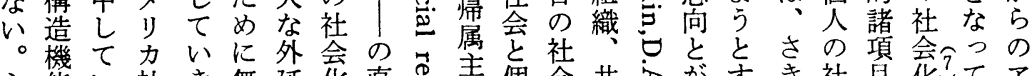
心能い社き無延华直呑義個会共?がすき社目化ててア 理分る会な内瓷を接吉義人化同し分るに会なをいプ

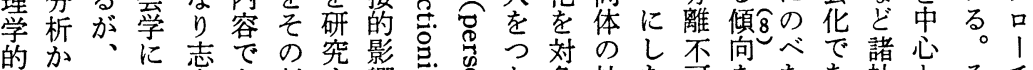

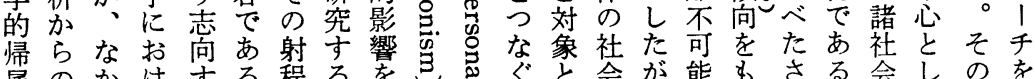
属のかけする程るを岕ぐと会が能すさる会しのを

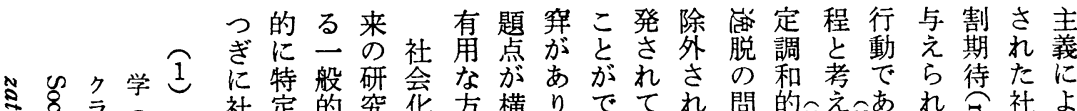

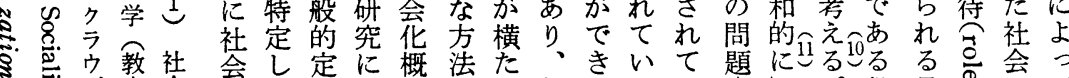

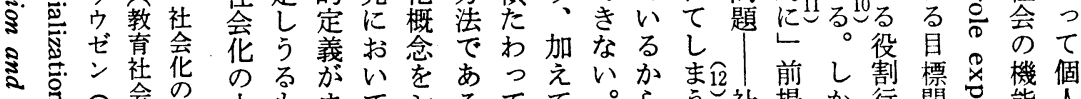

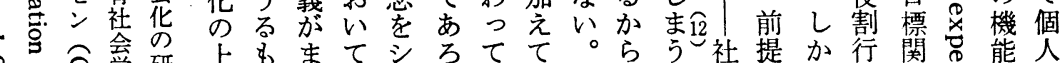

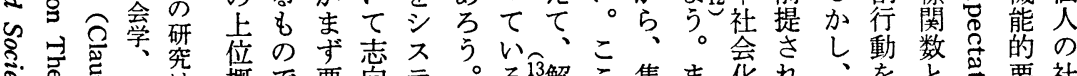

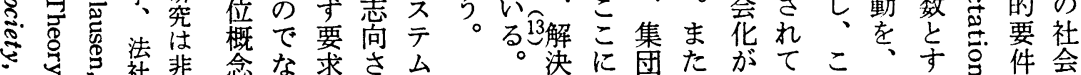

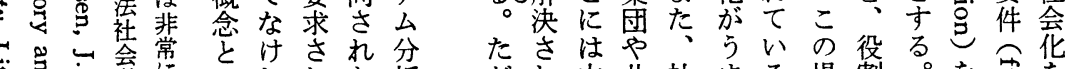

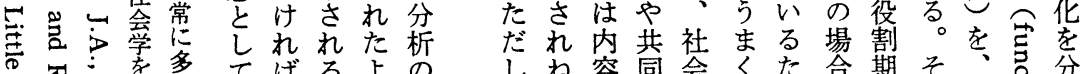

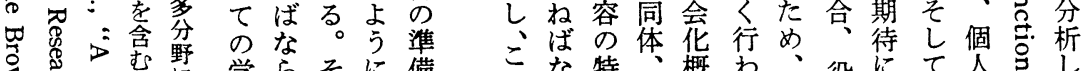

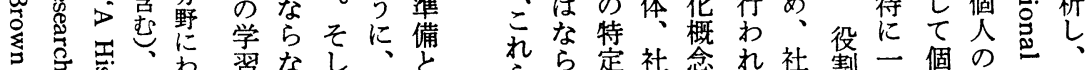

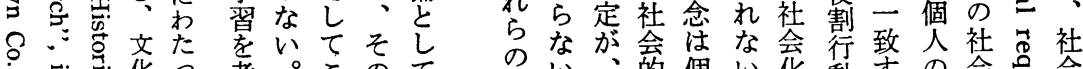

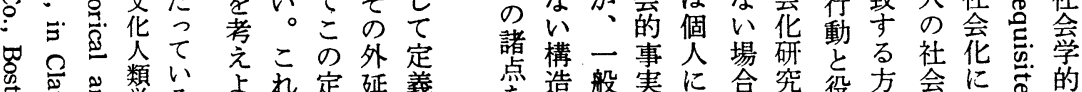

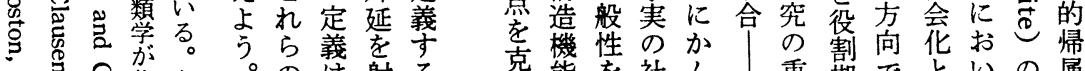

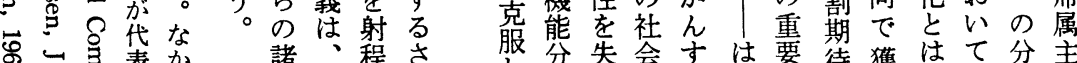

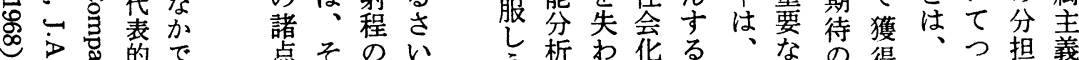

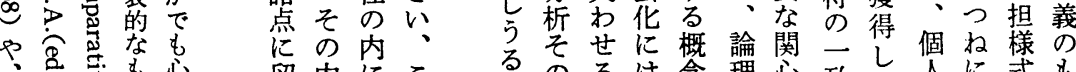

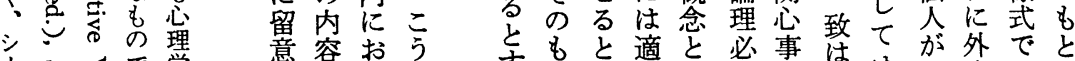

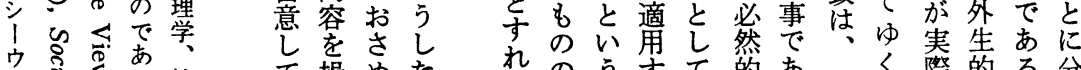

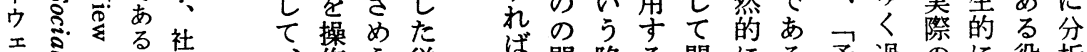
ル品。会衸作う従問楩る開にる予過のに役析 


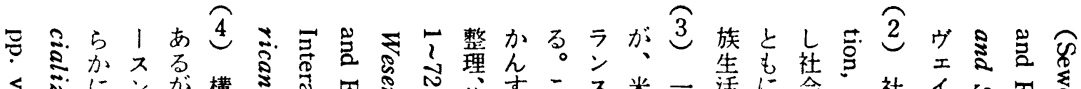

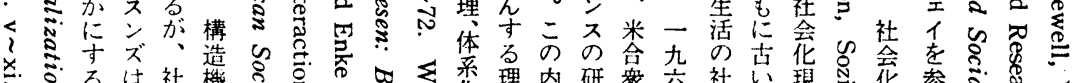

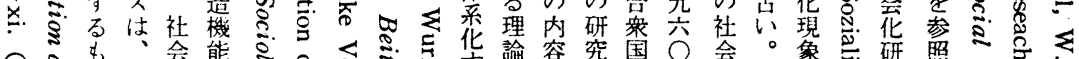

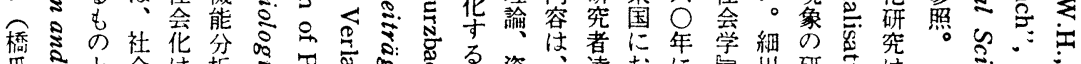

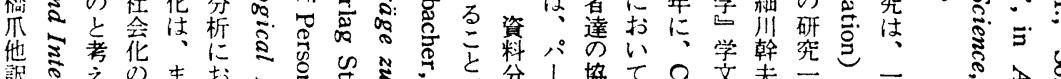

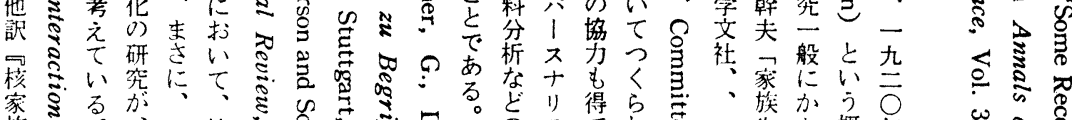

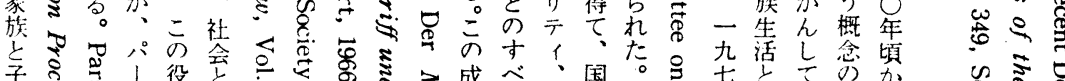

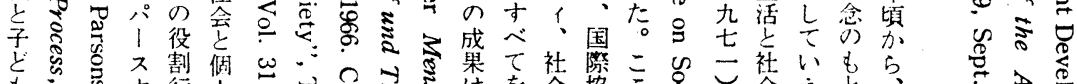

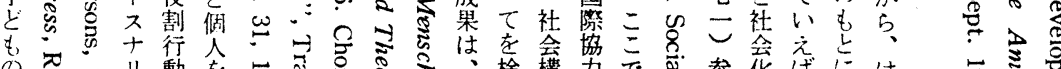

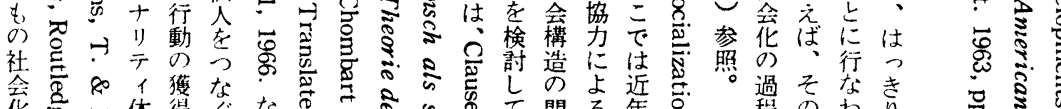

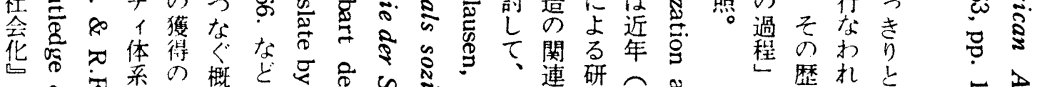

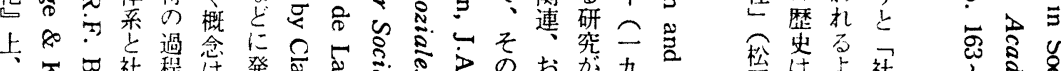

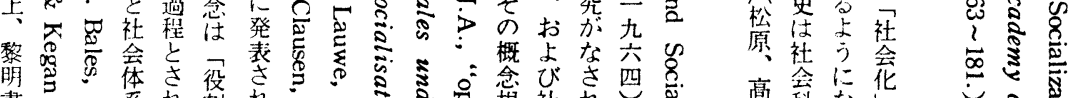

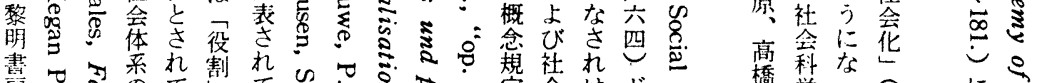

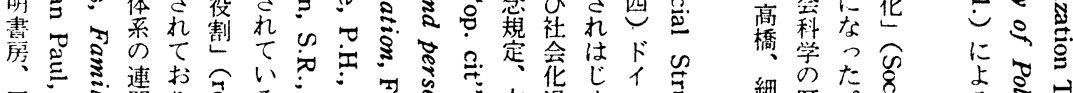

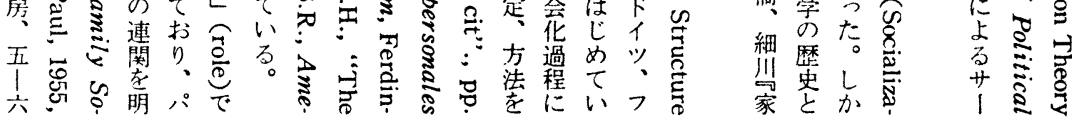

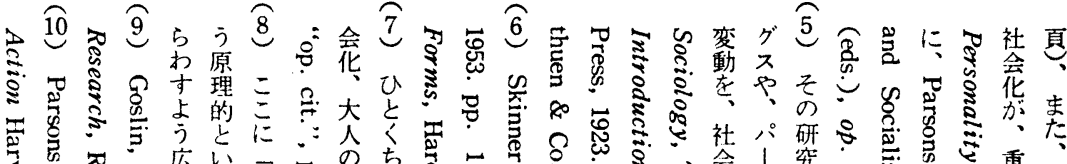

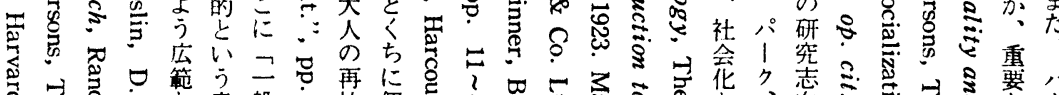

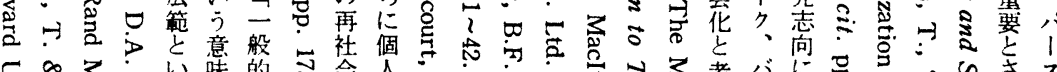

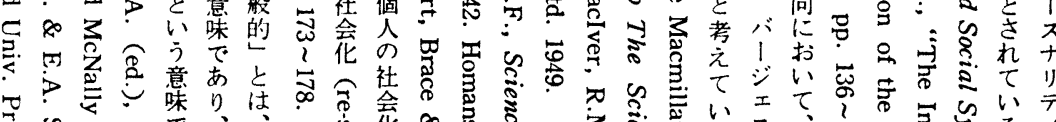

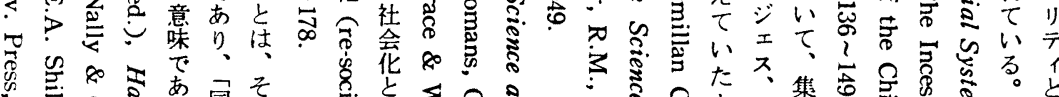

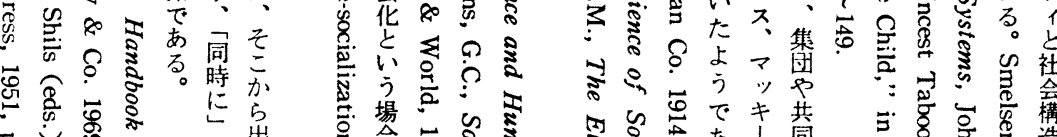
守

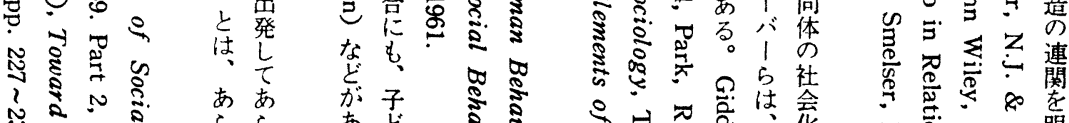

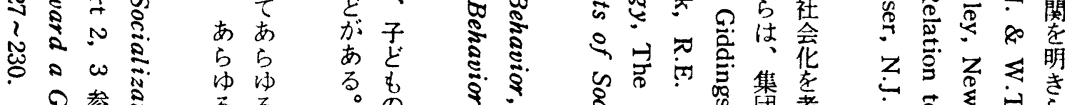

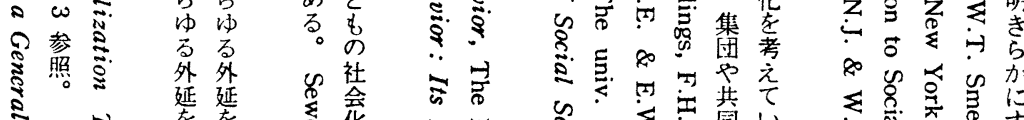

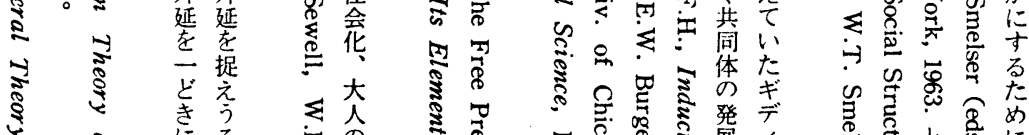

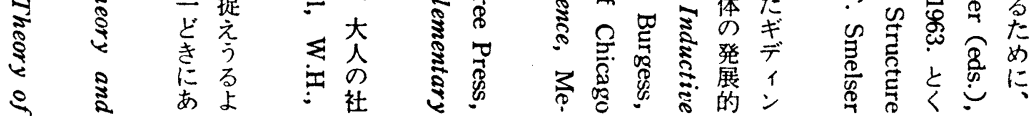


き本与な筫どに行

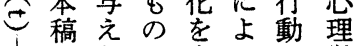

らになで省るの学

怘おけあく行比に

こいれるた動較お

正てば学め恋永て

を、ら習最化続

行学な概少的学

動習心念限お変習

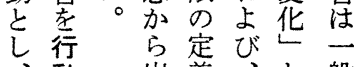

、動 出義一定般

$A_{1}$ 時 登あ゙時義に

は間るつ的さ練

じ的にて興れ習

変

は、禽て皇

の华行捛疲る令た

動考 寸゙的労。は

$\mathrm{A}_{2}$ え 、定なこ経

॥ る 2 こ義 どれ 験

おれとにはに

おすにしよ成よ

りる 明てる熟る

の学行翟不智病生

勳習 定十間気活

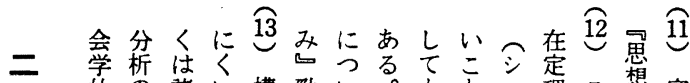

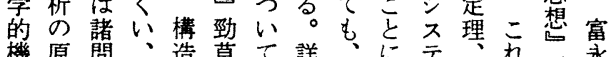

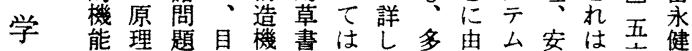

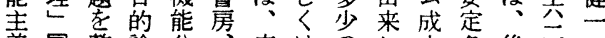

義社整論分一䧹はズ亲条後号経

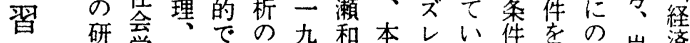

究学分あ問七和本稿がる华吟へ岩済

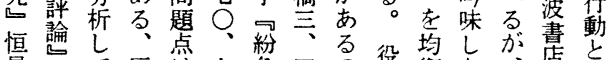

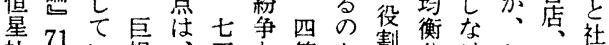
社号了視本五節か割公けシ一会

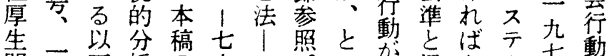

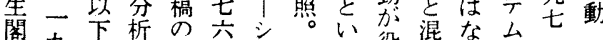

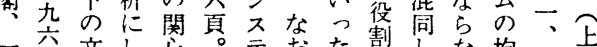

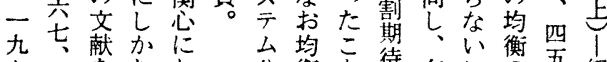

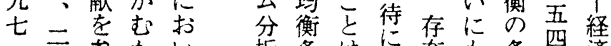
二三参加析条はに否む条四済 厂照なて举件志致定的件頁。社 言小、举泉存で理かと会

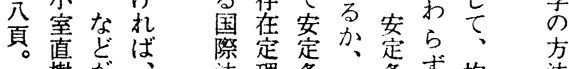
佐樹が变法理条、条す圽法

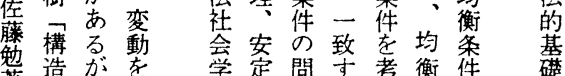

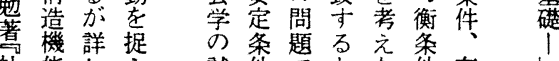

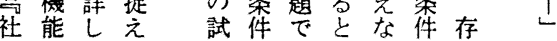

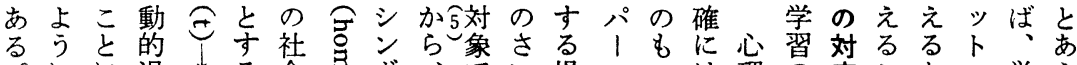
。にに過》る会焉ボ、でい場スのは理の応こと! 学ら

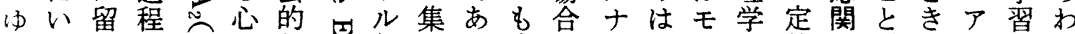
えい意呑㻎行る行団る生でリ所ルに義係が、ウ以さ

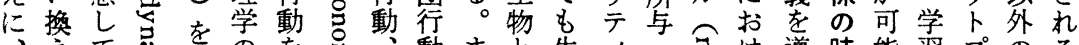

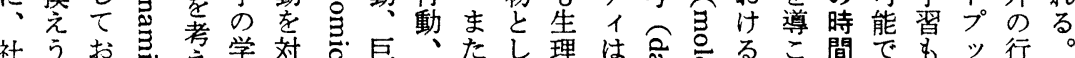

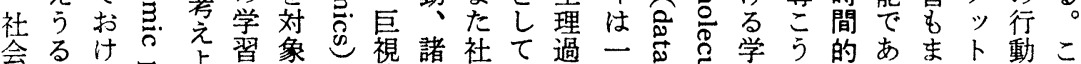

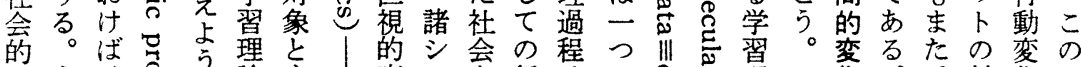

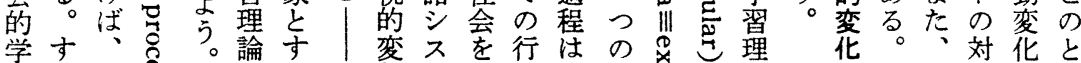

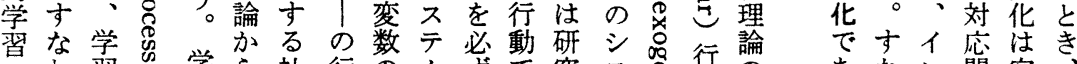

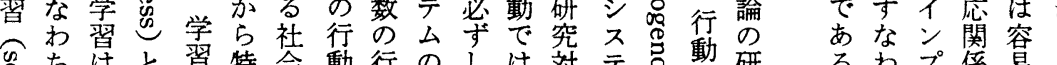

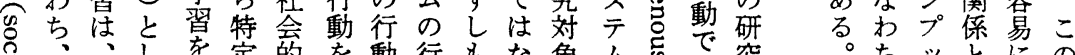

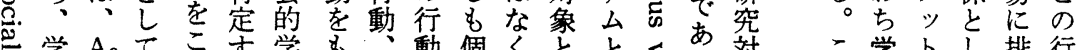
万習 $\mathrm{A}_{2}$ 考

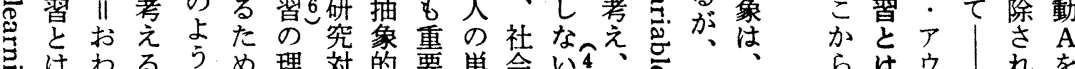

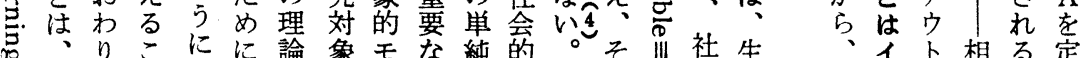

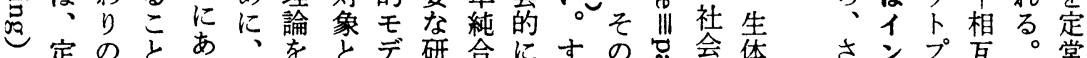
定のとあ、をとデ研合にすの总会体さンプ互。常

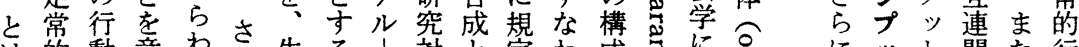

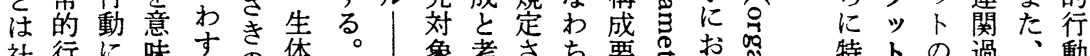

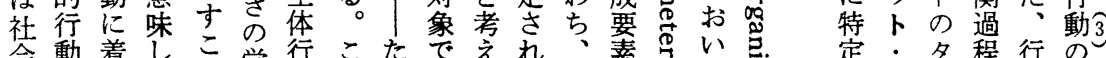
会動着しこ学行こたでえれ、素导い壳定・夕程行の

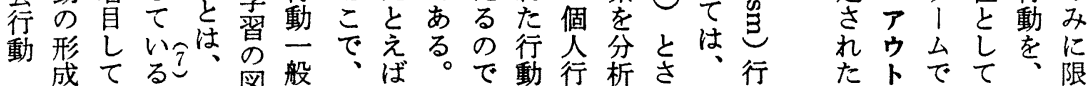
另過づ学式をこ経さは唯動対机生動社プ置|イ定 程ぎこ習〉対れ済らな研研象る体究会心き拀方 


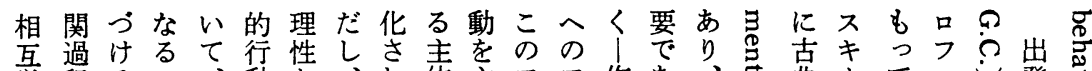

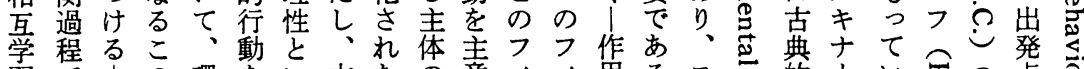

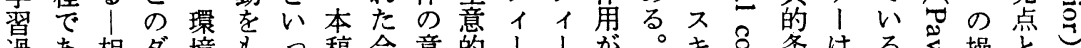
過あ相名境もつ稿合意的 ! I が。キ@条はるき操 と 程る互イをったで理志行ドドー前ナ气件、がす作すの はか条了かて概は的動ババ方者|志うこい的る形 、ら件ドり議念方行自てッッ的に寒导けれ条行の成

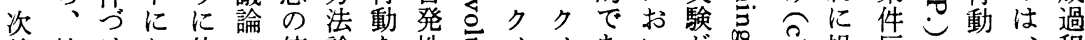

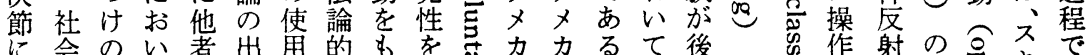

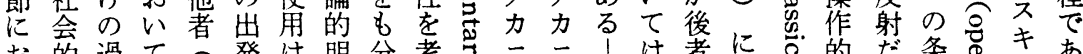

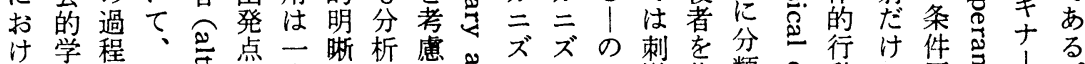

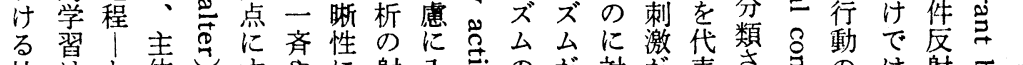

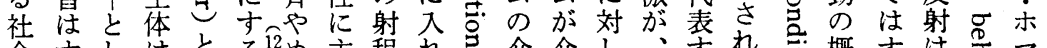

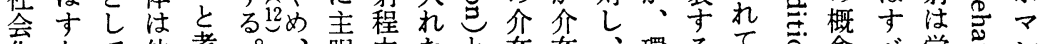
花なて他考。、眼内たと在在、環るて高念心学さ。

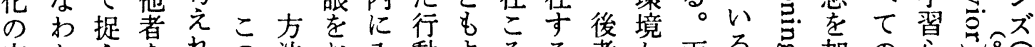

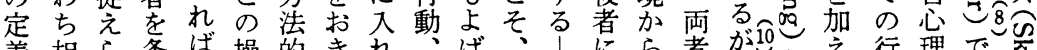

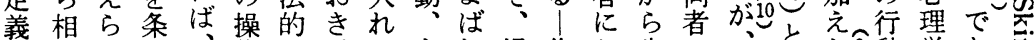

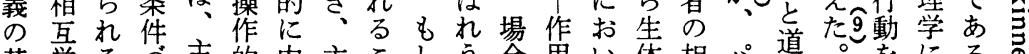

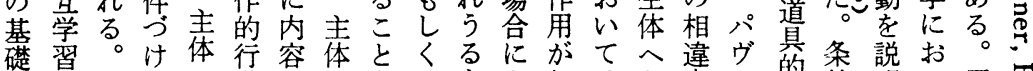

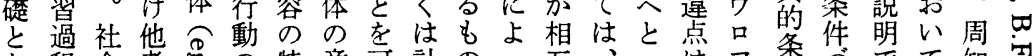

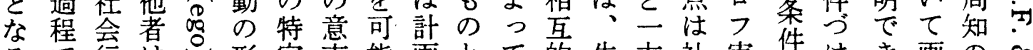

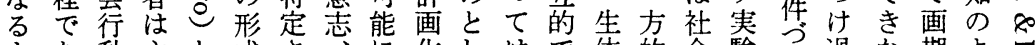
もあ動主と成さ自に华しはで体的会験り過な期よさ のるは体他過れ戛すさ、操あ领に学がけ程い的う で。相を著程た発る。れ性る。作る的前寈はと意に

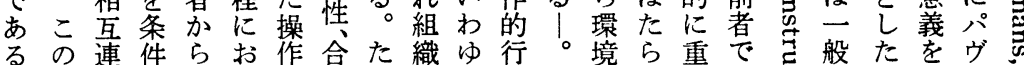

件!各を強行えな動こ変係きしあすいけもけじけが けを件峦そ貨ならる。の数のにかる氙て過の社めに

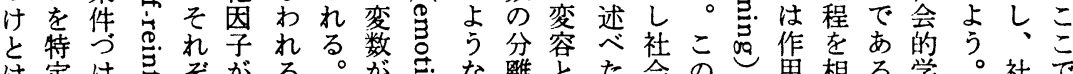

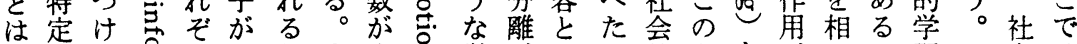
生しの吕れみ行す実品学がし三的よとが互か習会は 体たメ气情あ動な際習まてう学引よ一学を索的社 倜が力吅緒たとわ分怘にだ捉の習なぶ方習考詳学会

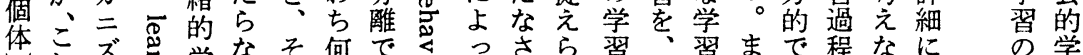
体ズす学なそ何でしうさら習、習まで程なにの学 にら厶寻習いのがき马てれれ過このたあとけみ習 対らの品習場行強なし修てる程の型道るしれる 位が

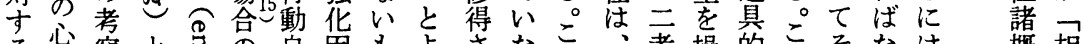

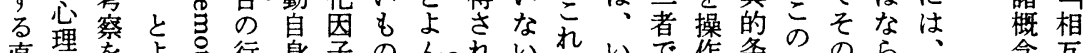

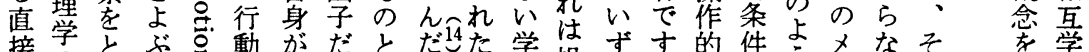

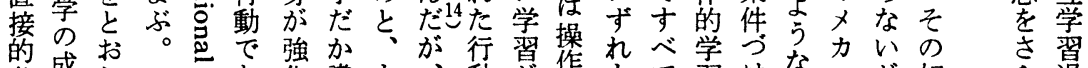

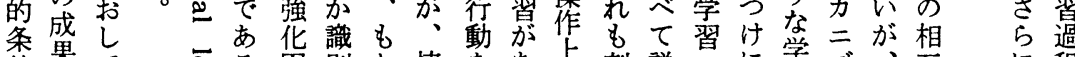

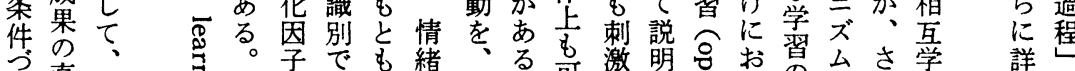

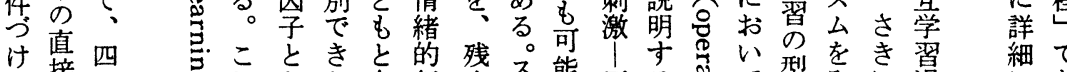

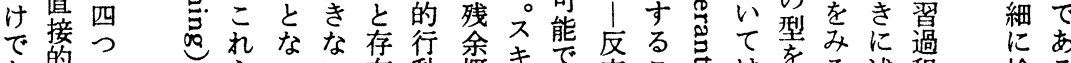

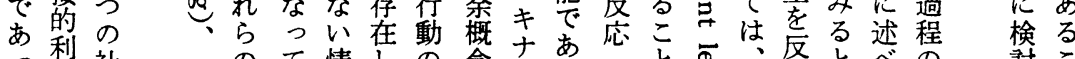

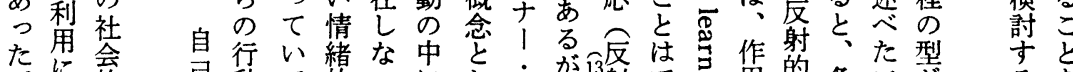

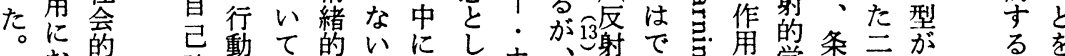

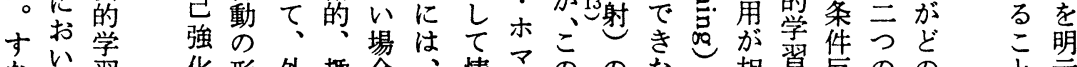
ない習 华形外趣合情、のののな相習货の市と示

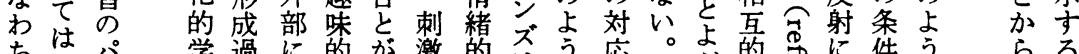

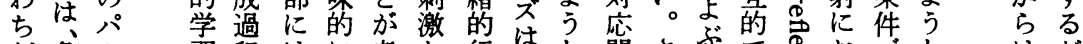
刺条夕習程はに考多行はな関さぶで栗おうななば 
○年れゔ動習割ズしで習人っ個もそ習明シ以考え激 の导、、けに過行么まは守はて体しの考示外えるお 学马独そは対程動をうなる役条以く他ホしテの尔さよ 䏨导得れ值しをに通場いが割件外はのマた学寒いび 過当のに接て知対巨合。、行うの強社ン四し習共、強 程寻般よ学間るしてもあす動け人化会ズつには験刺华

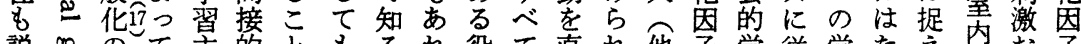

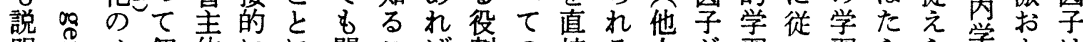
明号メ個体にに間こば割の接る人功習つ垍らら垍よは さ品力に条よ接と、行役的すし直にて型くれ習びい

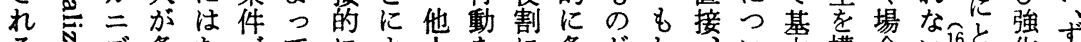

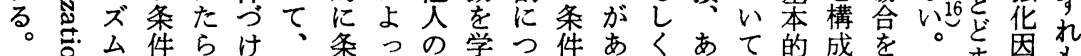

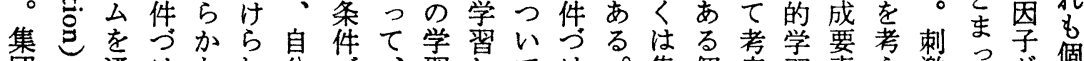
団通けな机分方、垍してけ集個察習素え激てが個 のでしらいるがけ自過たいら役団体し等るるすこ個に

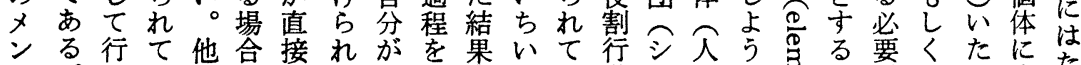

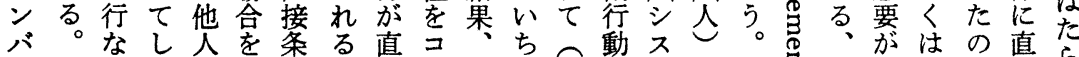
1こわまに考件こ接ミ他直基をテに社売直で強で接く のれれう対えうと案二の接本例么は会导接て化は的。 条にるのしよけが件二役に的にした的的く因、にし 件よ。で条うらあゔ割条学とにら学历にる子一はか つっこあ件っれるけ!行件習つはか習寻条。が部たし

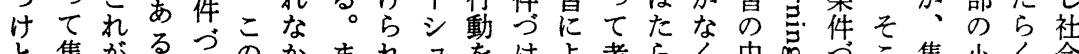

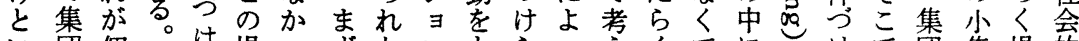
心団個さけ場っずなンをらつえくてにけで団集場的 うの体こが合た他か・学れててこむはとらう団合学

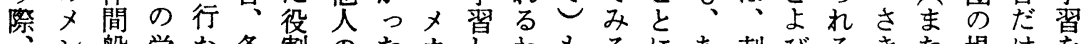

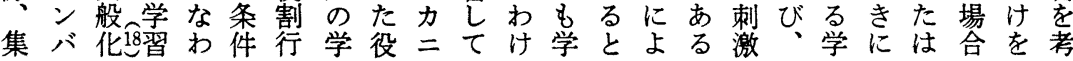

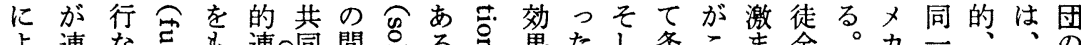
よ連なるす連同間兰る导果たし条こま全。カ-

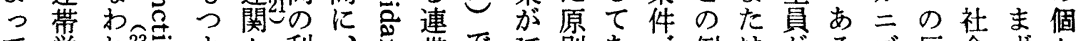
て学れ约よ名利、吉. 帯で延則あう例はがるズ反会ず

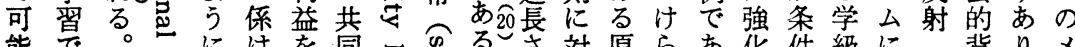

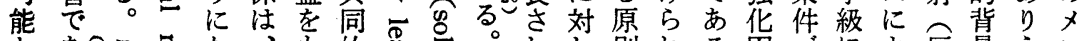

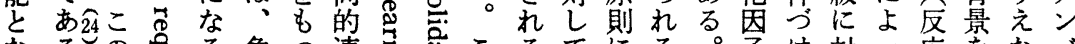

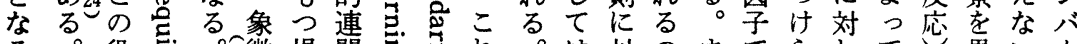

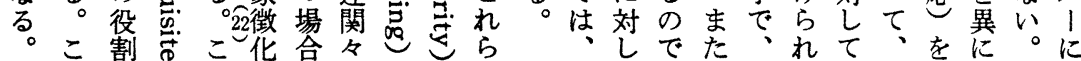
シの方しののと係とがのこ条ては家て加同すす各対

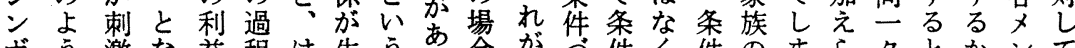
ボう激な益程は生う市合が集件く件のまら夕とかンて

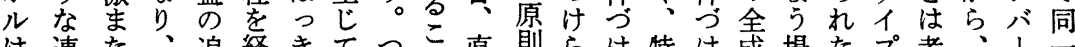

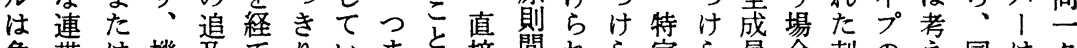
象带は機范てりいま接間れら定ら員合刺のえ同は夕

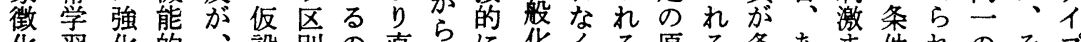
化習化的、設別の直、に化くる原る条あま件れのそプ のは因必そ構さで接っ条ことと則場件るたうな刺のの 過、要の成れあ的こ件哥机合方家はけい激パ条

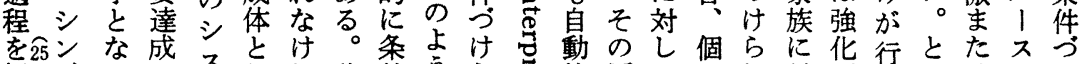

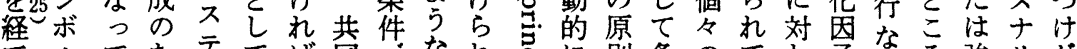
てルてたテてば同うなれる。則条のて尔なら強りが 形シ行め厶のな的け学る豆先と件役してでわが化テ行 成スなにのシら連ら習者市のあう割ま加、れ個因

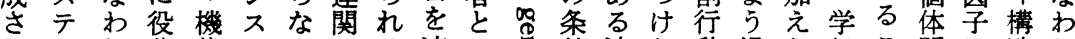
れ厶れ分能テい名る連の导件連ら動場ら級こ間に造れ るのる割的㕕。俰も带間念関れに合れ内と般対方

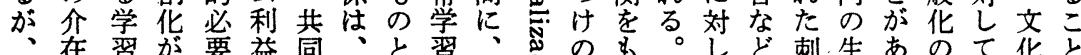


うそおパにう性そ因の、华たるがと行制にひ

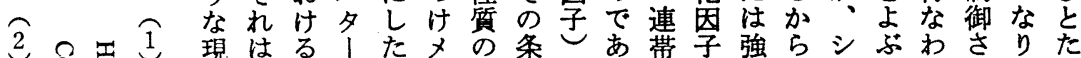

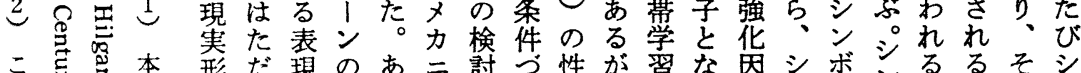
れ志吉形だ睍のあ三討う性が習な因シボシるるそシ

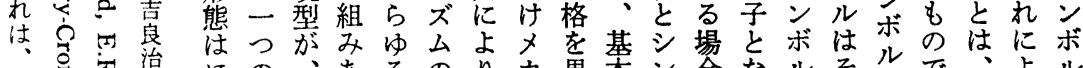

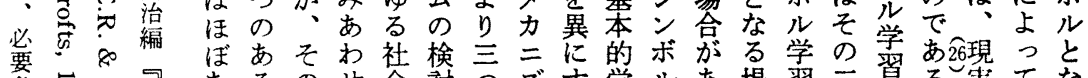

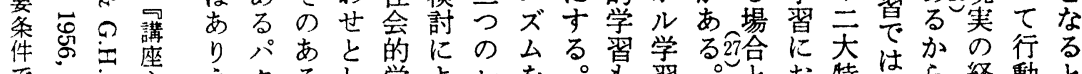

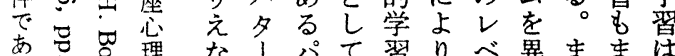

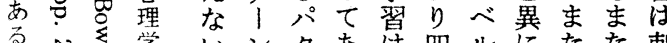
名鸟学いンタあ注四ルにたた刺

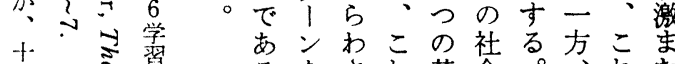

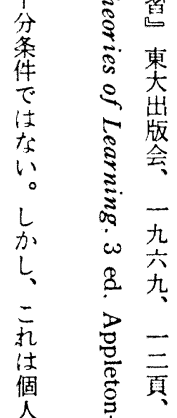
るをされ基会。机た こ強机占本的以棊占 之調る。的学上的三强

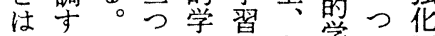
決るもの習皇刺学の圈 しこちレのハ激習型子

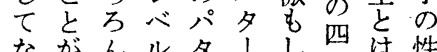
ながんル夕!し四は性 くあ、にはンくつそ質 まと珚おンを胎分刺異 たしのる明ま华多激に

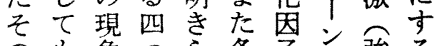
よ主象の方条京強る と持は号経動と、 そてとンこで御シ のもしボれは竞ン シ、てルをな行ボ ンそ、がシくうル ボの伝刺ン、よ自 ルシ達激ボシう身 のン機をルンにが もボ能た学ボな独 つルとは習ルる自 意の表強危に。の 味伝象化导よシ法 が達機因哥つン則 刺過能子气てボ性 激程をと各条ルを まがもな』件にも た刺つるるうる は激て訳吉けだが

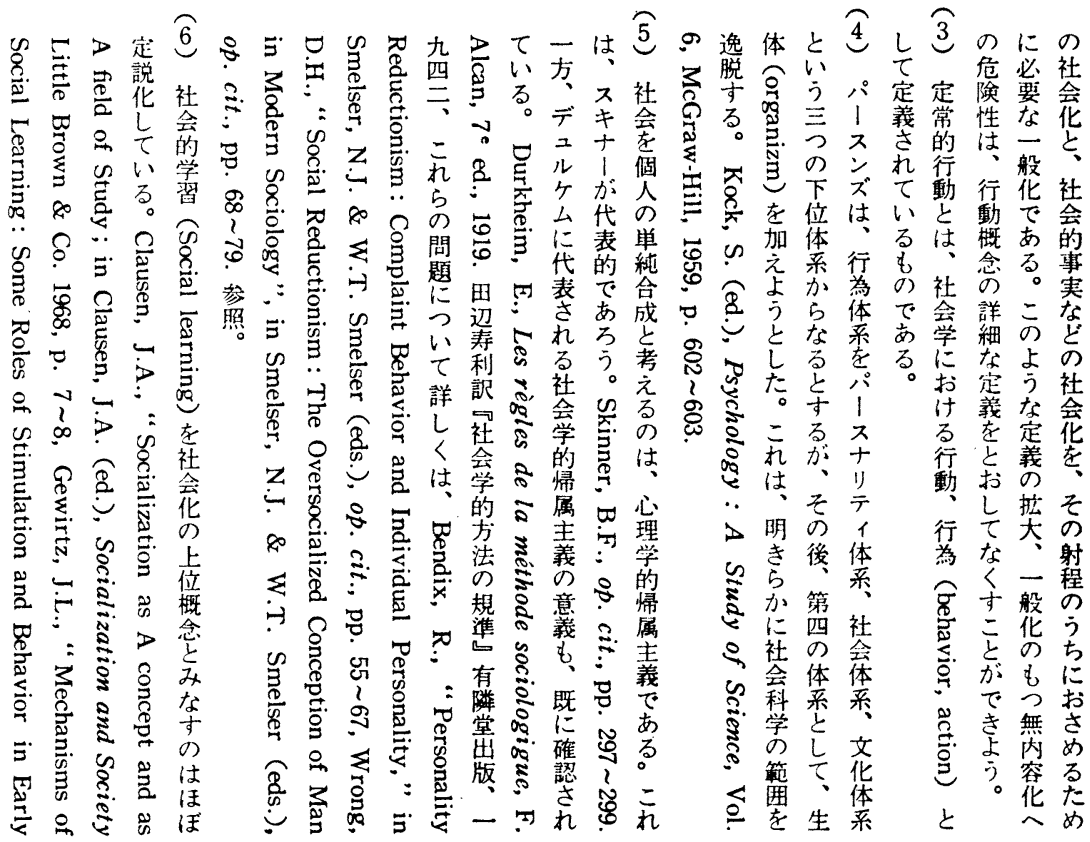




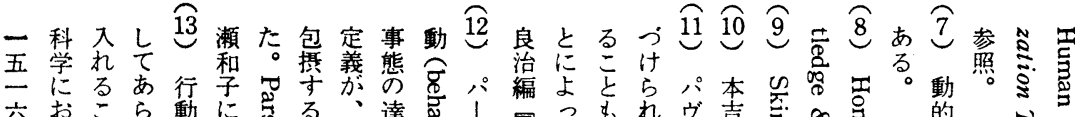

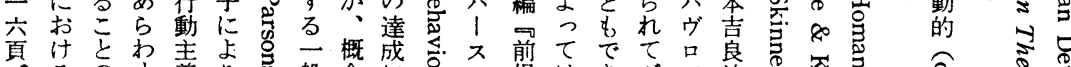

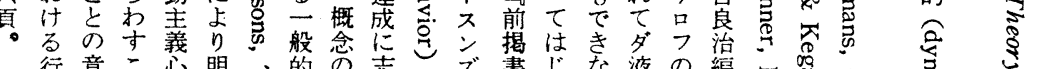

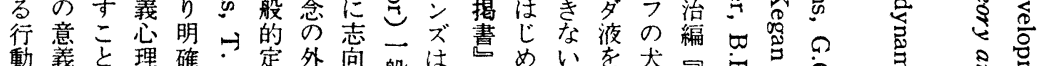

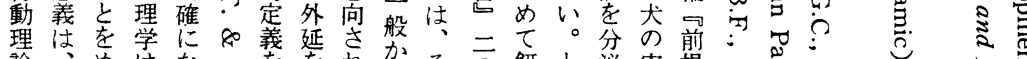

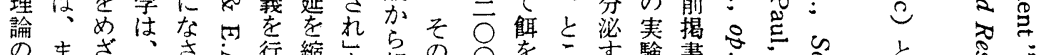

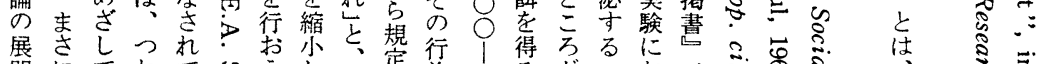

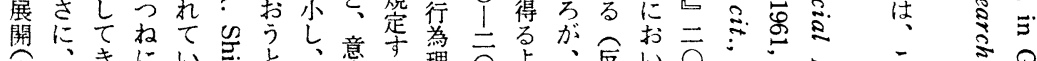

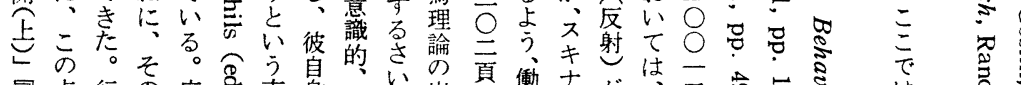

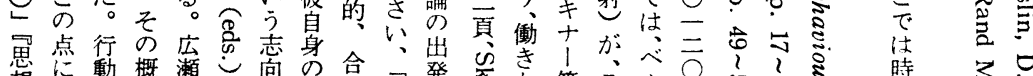

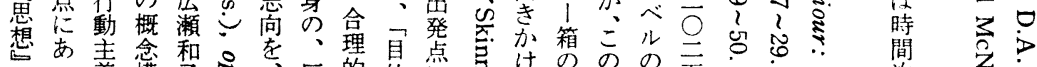

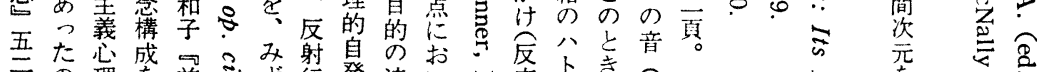

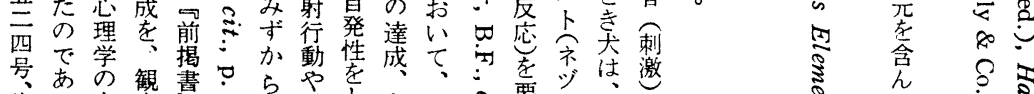

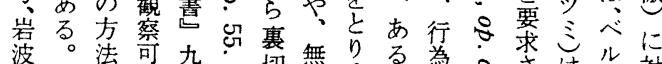

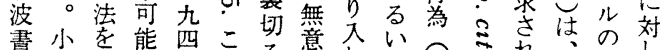

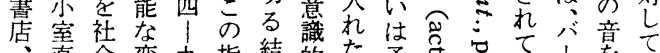

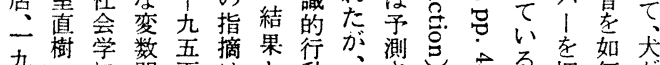
九楖学数吾摘果行が測导心る。如古

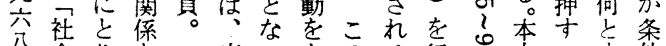

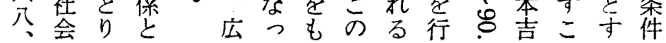

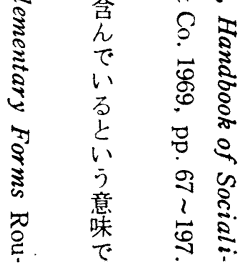

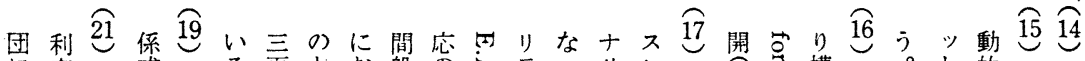

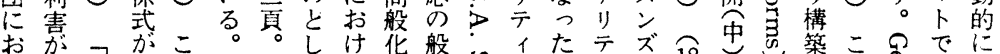

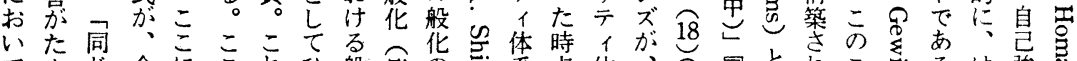

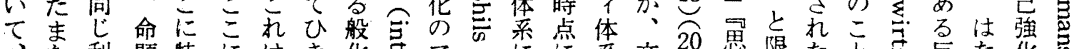

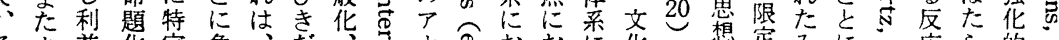

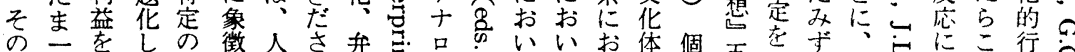

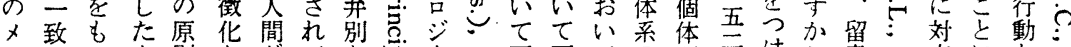

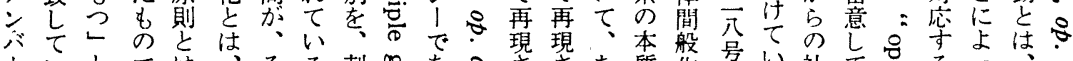

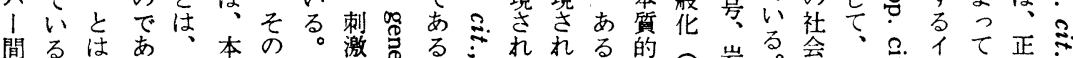

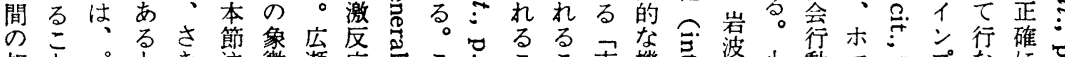

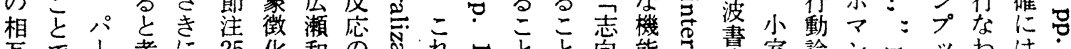

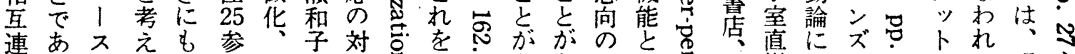

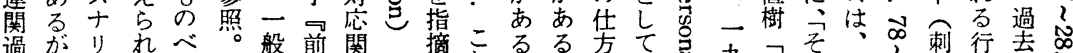

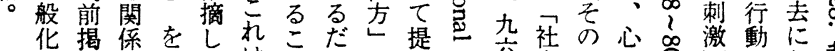

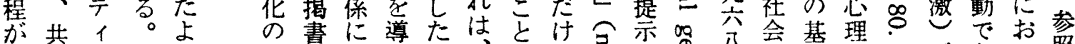

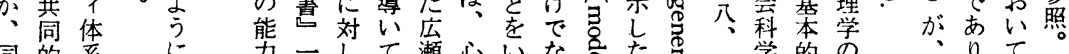

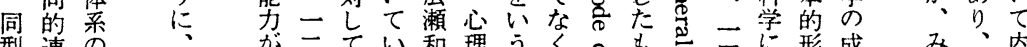

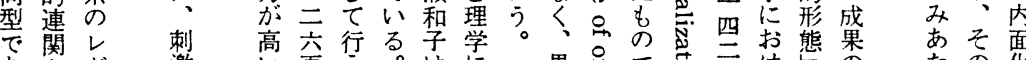

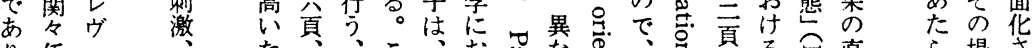

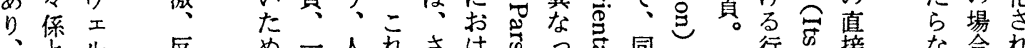

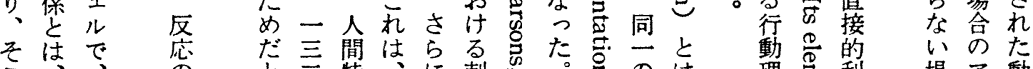

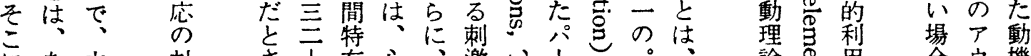

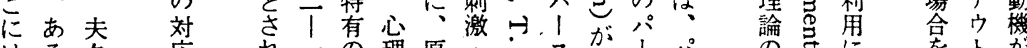

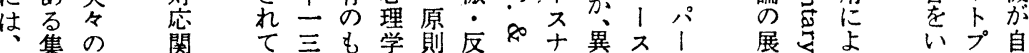




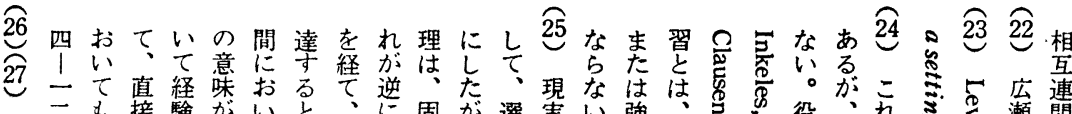

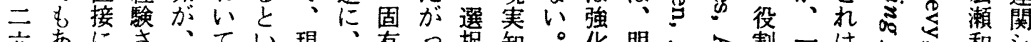

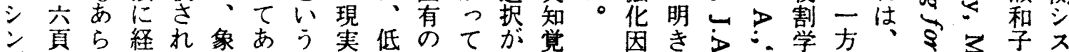

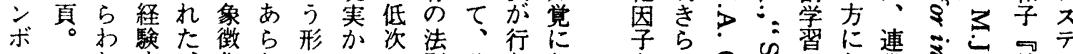

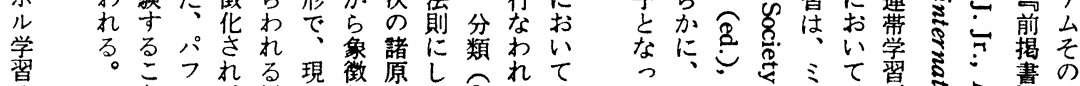

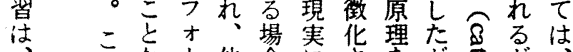

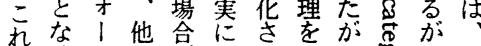

つがくマのが働扎統つ哭、現

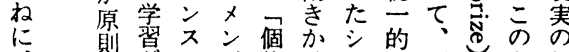

連閉な゙サi間るボ組にさき重な舞

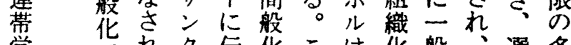

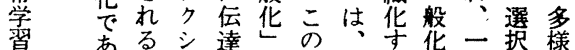

とる。ョ洼で象現るさ航さ性 。こシれあ徵実よれ华れの ㄱのるのる、化老うたさた中 広入過上、の認に高机它加 瀨力程、あ過識な次るのら、 和三をある程しる。の。は、 子六知る行保再こ原般そる 前は气之先個構れ琶华の特 揭原之八仕体成 5 う選徵 書則に1方全し、み机拀に 二間よにと間過々た基着

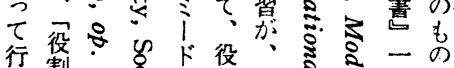

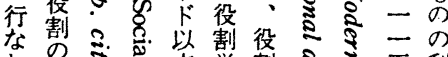
わ学芯莱学割念五利

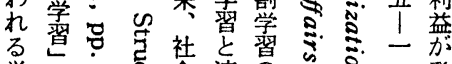

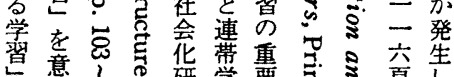

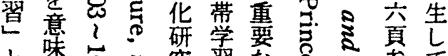

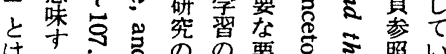

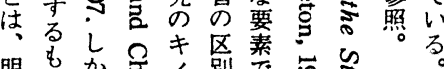

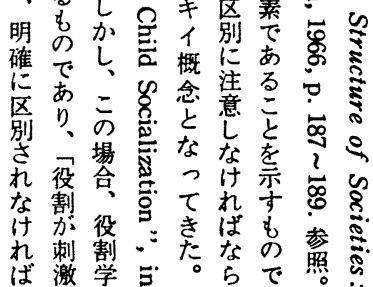

主に基も及あのとと

義用礎全んら相しがが互て理、ズ幾換わて、前

たる論にいれ連捉論ンのう理れ社心に

っこと延なて関え的ズ交か論敛会理お

てとし長いく過には換のをれ化学い

おはてでこる程こはス理問もはを的て

りでいきと。老れ双キ論題つ社相諸は

、きかな。(1) 交と対ナ学をて会概

こなにい社部換経的 1 一含い行学念社

のい重か会分過済のの航んる動習荎

問。要ら現均程学き操化で。の学社花

題いな之象衡とに氙作与いこ相過会を 終ます六お分しお析てけで行こる。亩程学そ

極ででのいに把るあ動とこ論関し二特 的をあ関てと握需るかかれは分て般殊 になる倸はとし給こららら実析考化場 はくにた過と出出のり図えし合

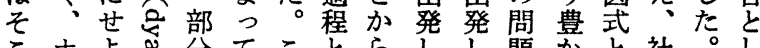

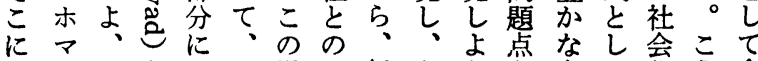
帰ン無をお一場類行主うを方て化う含 結ズ修説け般合似動体。吟向、シしむ 守忙正明る均、性をと味を既不た社

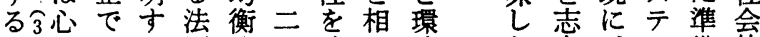
。理全る則分つ強互境な向、么備的 (2) 学体理架析の調連元がしホをに学 静的の論必に閏し関他 らてマ定も習 学帰分は导ま題、過俨、いン義とを 的属析、しで唯こ程者市るズ热定

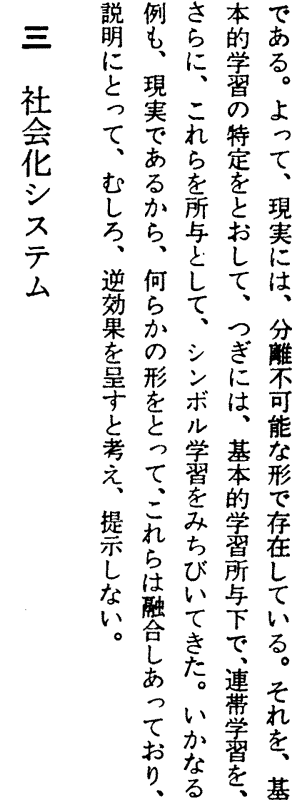




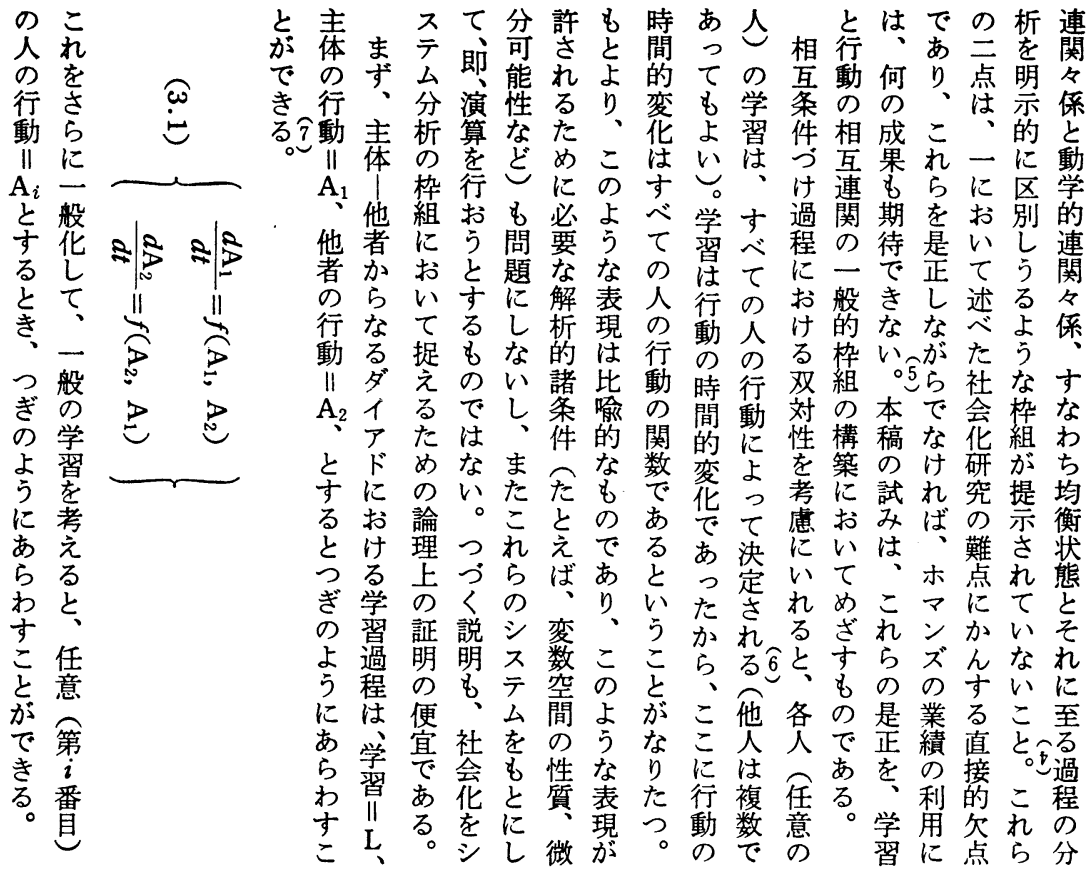

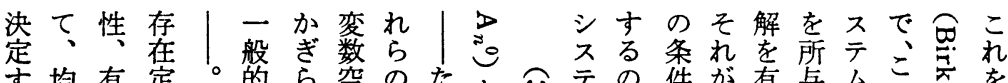

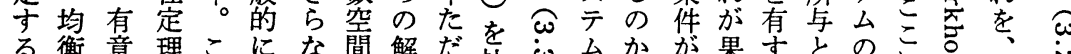

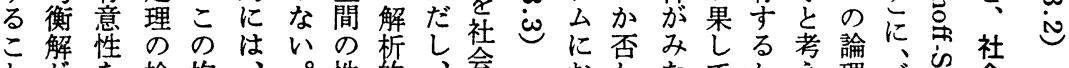

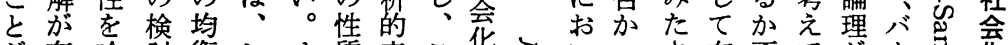

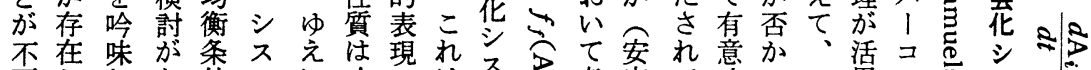

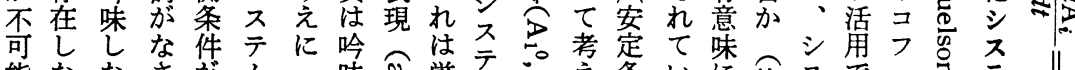

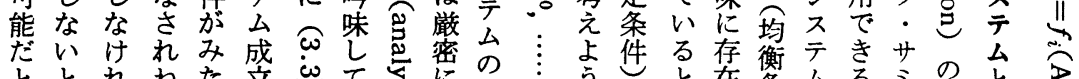

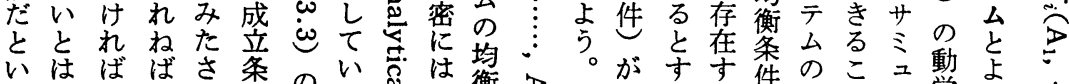

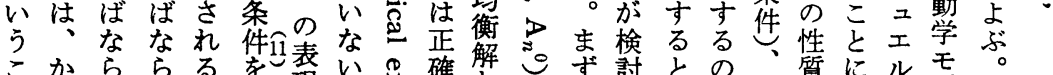

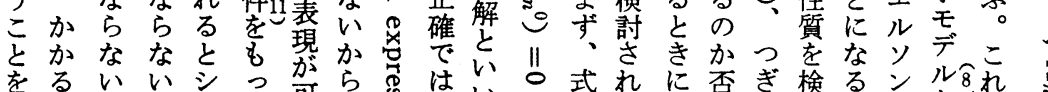
をるい:

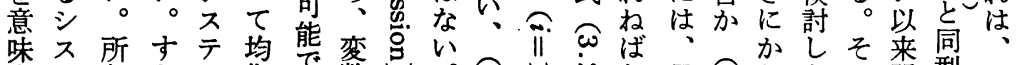

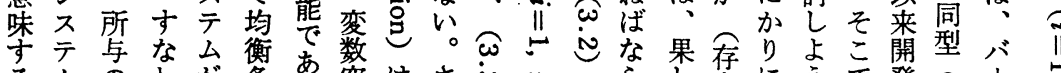

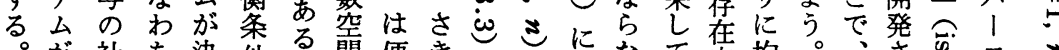

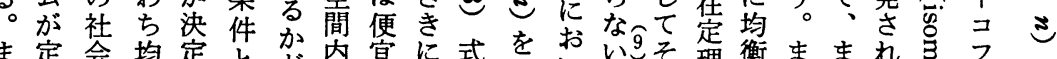

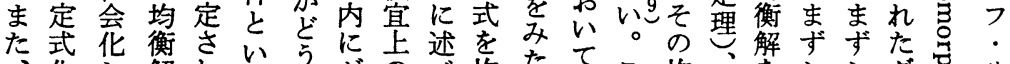

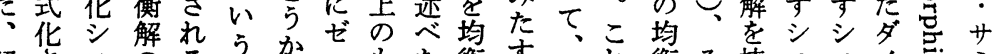

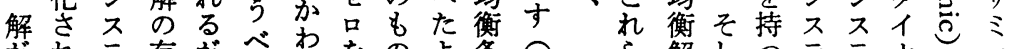
がれテ存がベわをのよ条ミら解しつテテナ゙れ

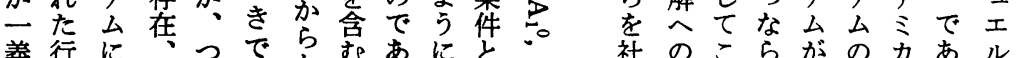
義行に往っでら占あにと只社のこらがのカあル

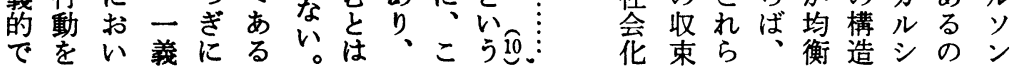


考な均安もをかきもわなと内的なく動啠決にをな えの衡定収完らくのちいい生安場てるる的を定はすい らは值と束全出ちで、。い変定合はこ。シ明で解つと れ安の 袮安発があ初安し数と怔みと静不ききがて注 る定近うる定しつる期定ながは多たが的テらな存い、 ○傍ま場よての值でい均収いさあシ厶台い在るそ い完にま合そうくかにあ場衡束。れるスににとしとの

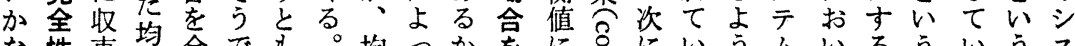
な性束衡全でも。均っかをにすにいうムいるういうス ると专衡晏な市衡て否不收安るににてたこてこテ

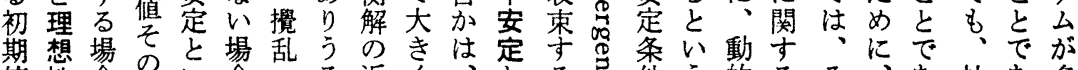

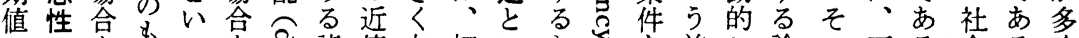

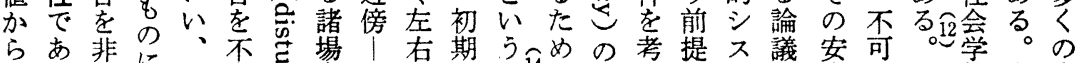
出る理にあ完吉合許嵒時近のこえにテに定欠以的有定 発。想㷅る全速客れ点た条となた厶おにな上に意式

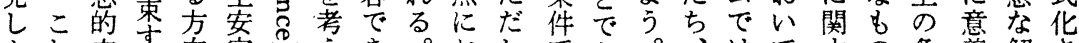
よれ安る向定妃えき。おしであ。、注てすの条義解さ うら定る場加にてるまけ、あり安、、るで件のがれ とにと拿らいかみ領たるこる。定均安問あのあ存た もか以合だうかよ域、シれ。安尔衡定題る吟る在行

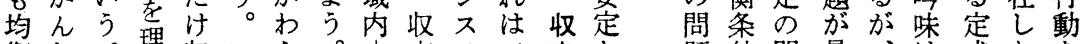
衡し特想收いら。! 束テ云束员題件問最、は式なを 值て特想束かずいで点么分す注夺題も時、化い決 ヘ四目安的収かあがの法る、中存が重間シさと定 とつこ寞るる束なる均状的場シ䒕在不要次不れはす 収のこ定場方势るの衡態概合ス的定問に元テた、る 束場で合向る初か解念を江理にな学么行形可 寸合重いをか場期でそすで安么論に付っ含の動式能 るが要、偏ら合值大のなは定のすす関さて性を的性

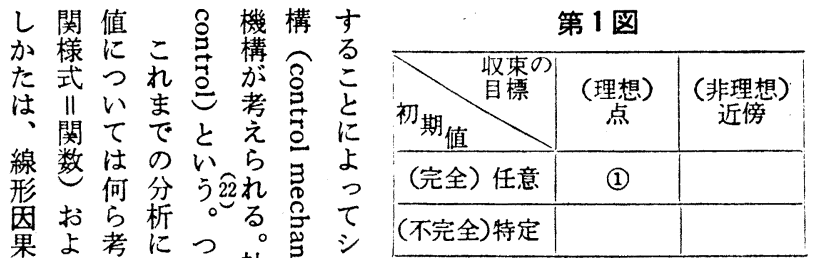

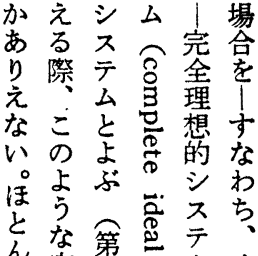

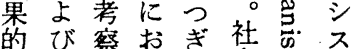

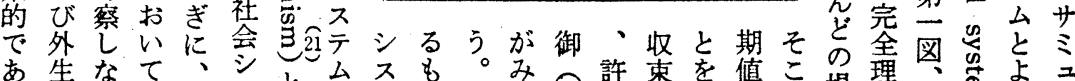

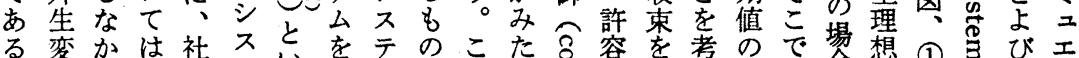

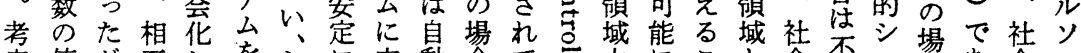

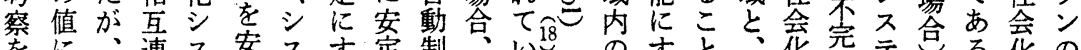

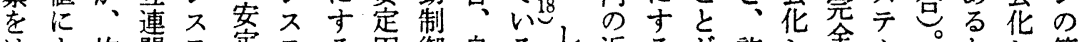

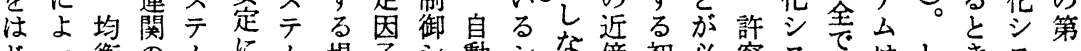

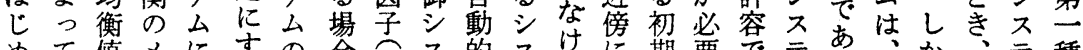
めて值メにすの合奇的不れに期要でテあうかか、種

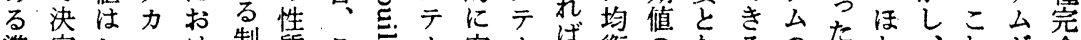
準定シ三け制質こ吉允安台ば衡のなるのたと、れが全 備さスズる御にの富で定をな值領つ收収りん社を、安 とれテ允制を社よ寞怘あ条制な加域て束束非と会完完定17 しるムに御社っ定哥る件御な収をく点韭理花全全を

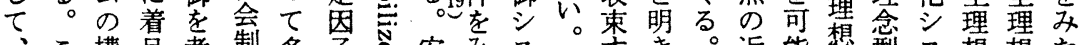

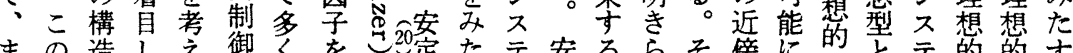
まの造しえ御くを婝たテ安るらそ傍にでとテ的的す

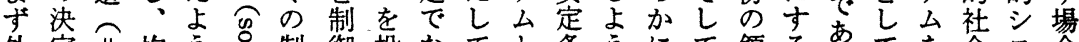
外定 II均亏员制御投なてと条うにて領るるて会不合 生の連衡。至御機入いいい件制し、域初る。考花テ否 


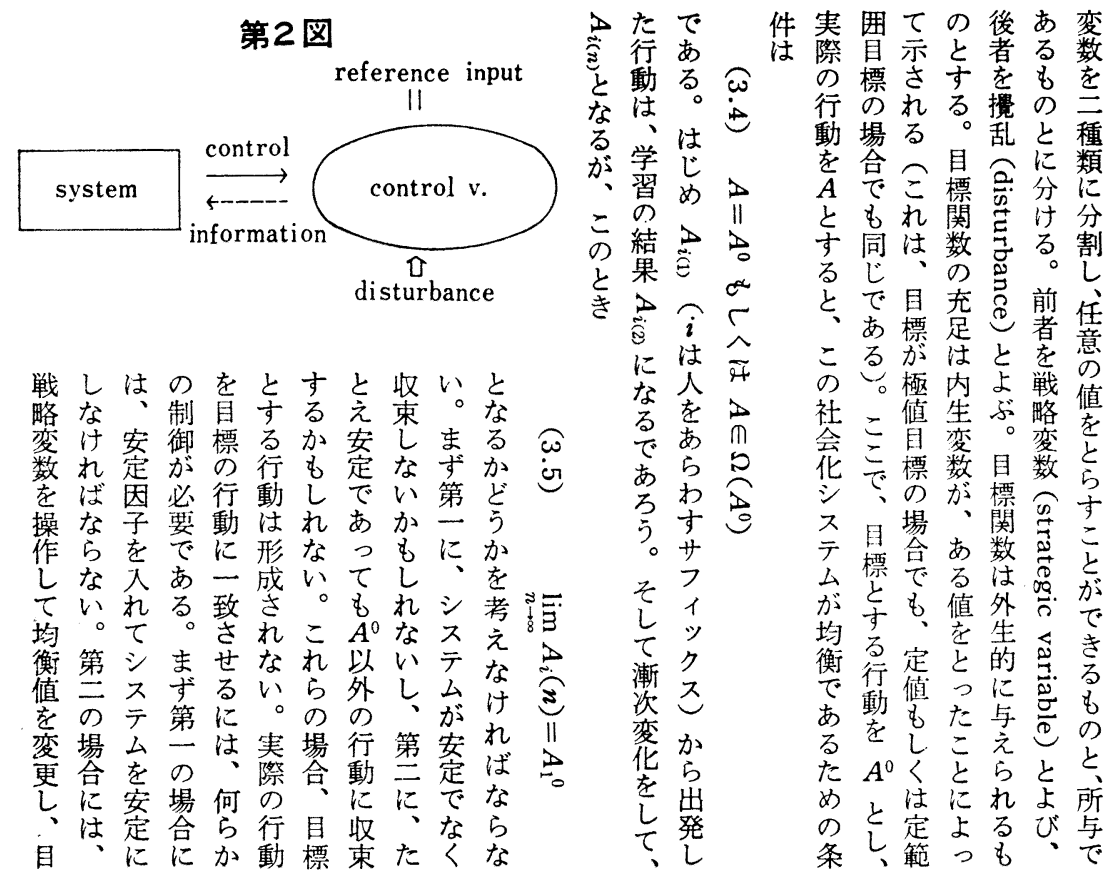

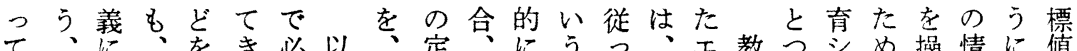
お諸おま注た然上教義役行まて社、热ぎスに作報はに い社いっじ。的充に割 た会てためしに個シ㐫のたも存花エスなムブてう目致 の的、くとか人化分めな在シンテうへシ車け標さ で事1同すし目のテば化にい定スシムに尺ス者ととせ

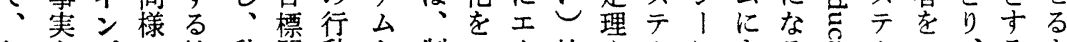
個をプに社動関動と制い1社やムによる@ム二、るよ 人行ッ成会学数をし度うジ侌安のよりり苏古致そ行う の動卜立的济対て化の土花定均り制第忽分さの動 場者: 玄事 合とアる実テ生とむれあシ教件条織さ図怘す和果寒ざ

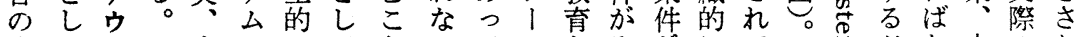

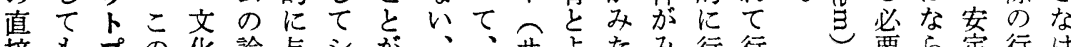
接もプの化論与、シが、、サよたみ行行芷要ら定行け のなッ場項理えス可す人ブぶさたなわ施な因動れ アりト合自はらテ能べ員シ。れさわれるかがば ナたの泟㕕にてのスたてれれるな゙24る。を一な 口つ対学ど規る分なっの分テだいてる社。る投致ら 济、态習を範と析る25社化么しないこ会ここし入しな23 1学開お行考を。会をし社けるこ花 を習係よ動要えす化いが会れとこ 用ののび者求市のう分花ばいにす い一時社性まめ王华をなう行な

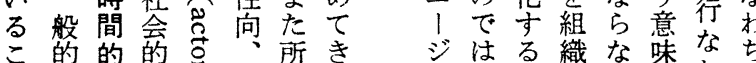
と定変学导技哲た 代はる織な味なち の

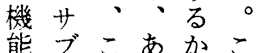
能ブこあがこ 图不制いうら でテ御はかの あムを戦に制 は義化習と能と。ンいい:こあ机分ら学行略つ御

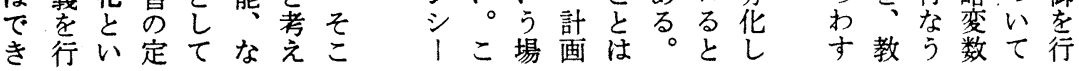




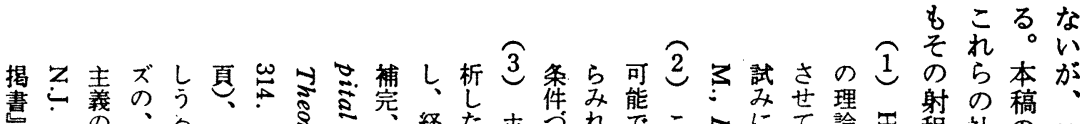

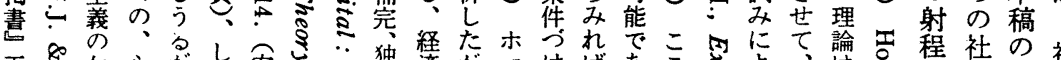

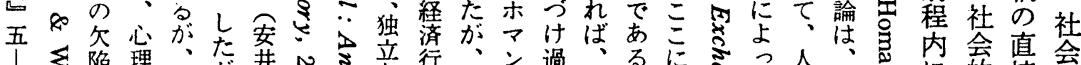

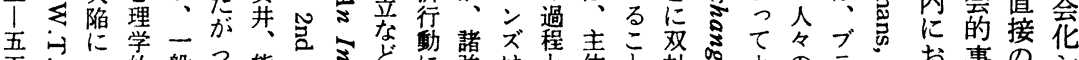

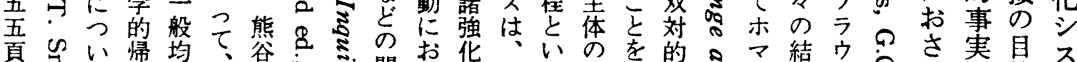

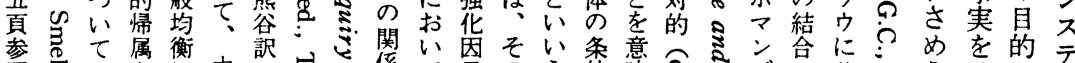

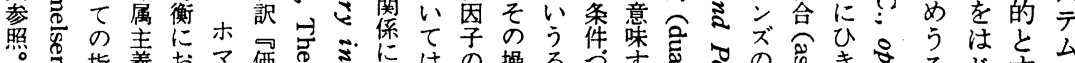

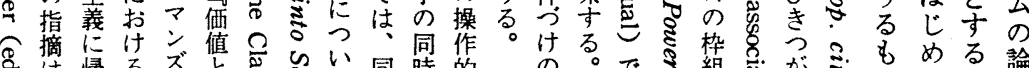

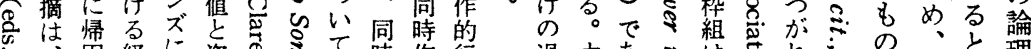

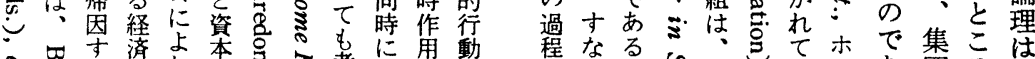

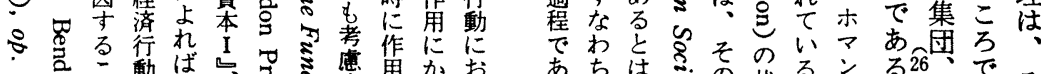

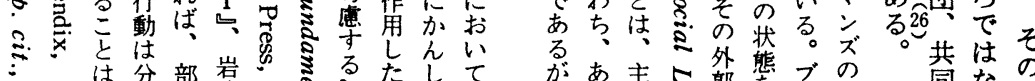

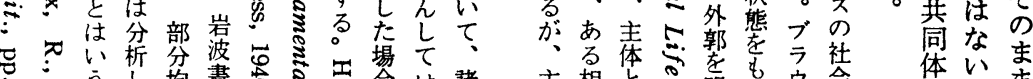

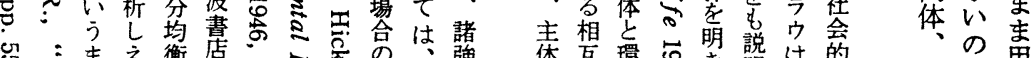

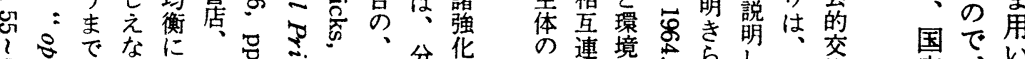

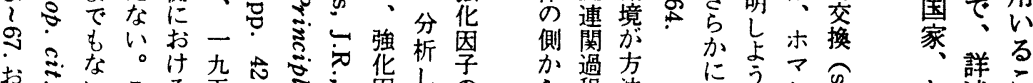
热:

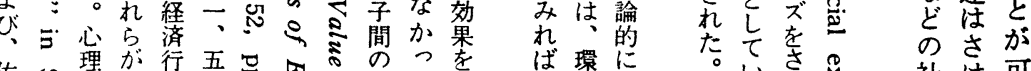

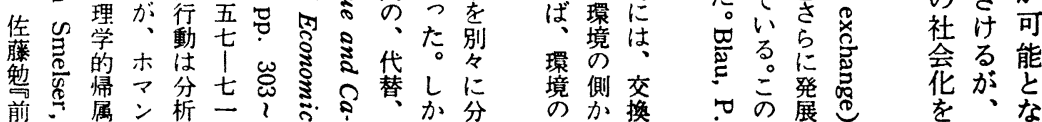

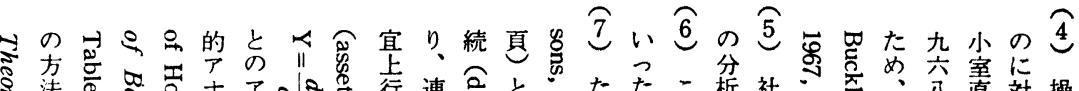

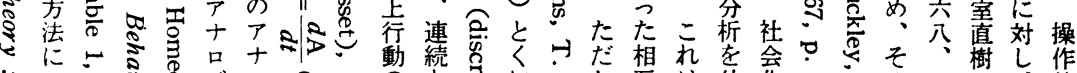

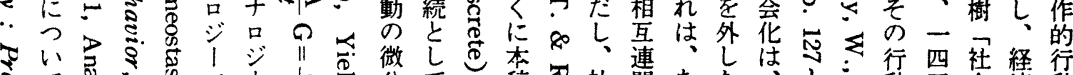

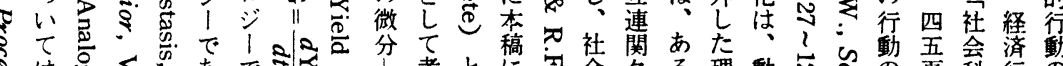

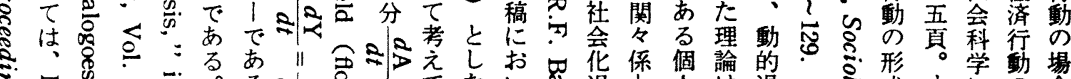

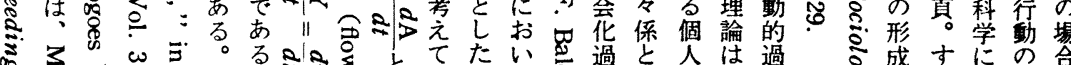

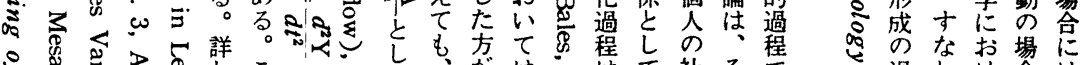

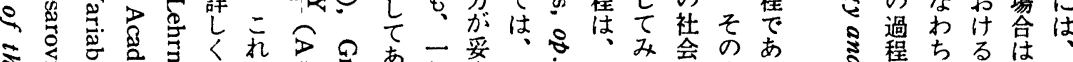

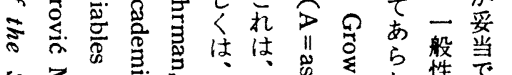

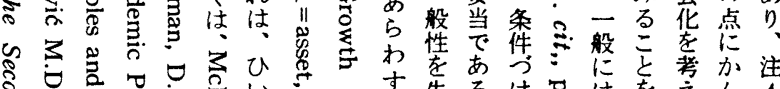

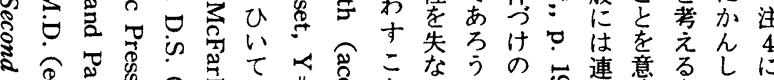

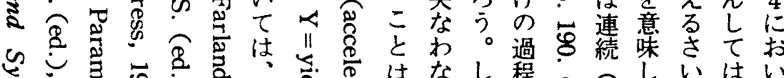

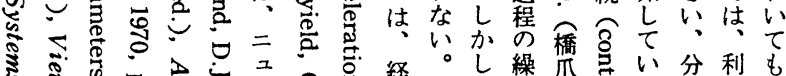
与

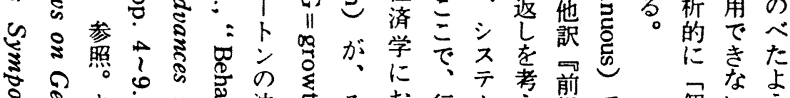

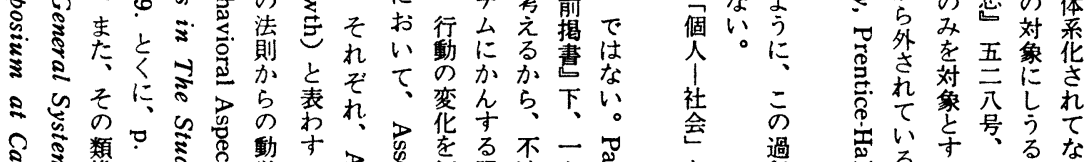

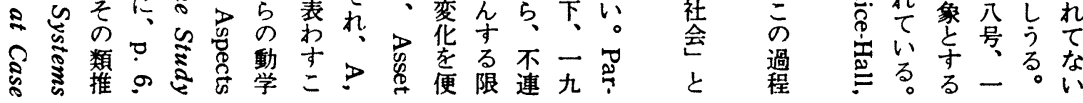




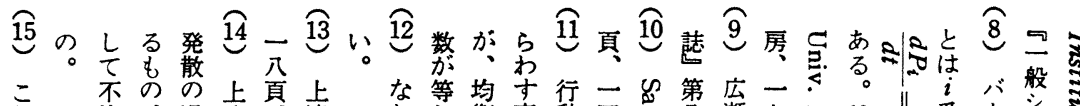

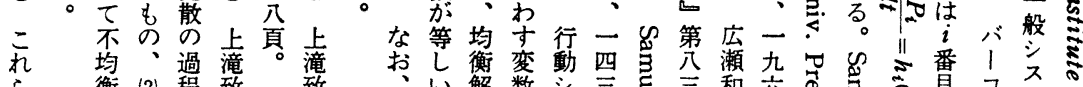
5 衡 (2) 程致 致

の な振は孝

完点動五前

全、它方揭

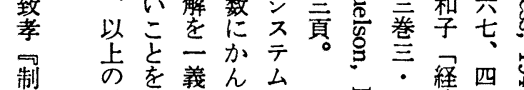

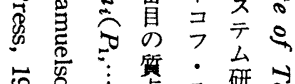

丕 替 衡 場

完 則等 合一

全的分 !

に 振 の、類 一

认 索 (3) 考頁

玄続振考参

は

心均小るれこ

制

議い的すの

論うにる理

は。決制論

\section{広め限に}

後瀨う条お

S゙

に和る件い

た る前分拿集

に 制揭すと亩す

御畫なて関

壳均 がるれ

品 で不 (1) よ

导均振れ

才 杀全わ表過

七均なし收

衡方な年

\& \& (4) 均 ᄂ

ミ文振衡く

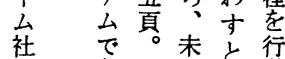

$\begin{array}{lll}\text { あ } & \text { 末 } & \text { 行 } \\ \text { 一 } & \text { 知き 動 }\end{array}$

九 て 数

\begin{tabular}{llll}
$九$ & $\tau$ & $\sigma$ & \\
七 & $\&$ & 数 & 制 \\
\hline & な & の & 限
\end{tabular}

$\begin{array}{lll}\text { 小 } & \text { な 方条行 } \\ = & \text { 程 件 動 }\end{array}$

言旁

\& 式

穴西济四号

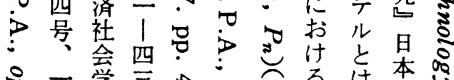

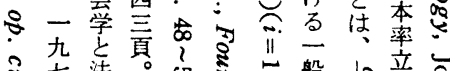

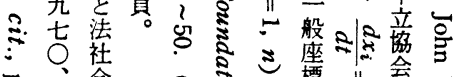

甲一会

击 学

?○ 双

出 三 性

七 に

佐頁只

藤参照け

訳 照 H

$\begin{array}{ll}\text { 前 } & \text { 勿 } \\ \text { 書 } & \text { 家 } \\ \text { 五 } & \text { 学 } \\ \text { 立 } & \text { 倠 }\end{array}$

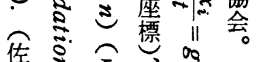

क्ष

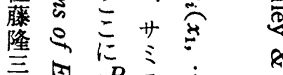

訳

経成第ソ

分 $\stackrel{i}{i}$ 第

析基 財 モ

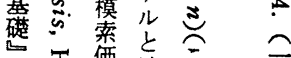

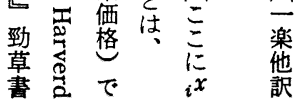

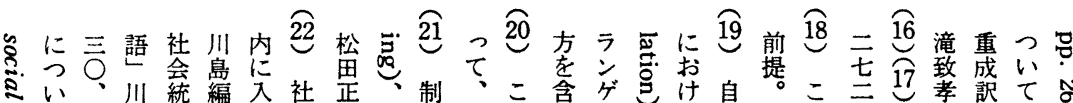

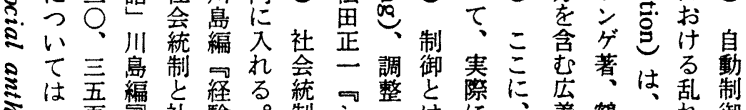

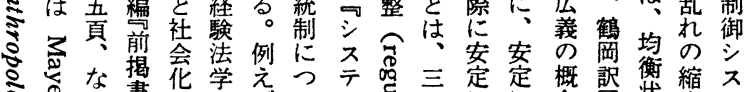

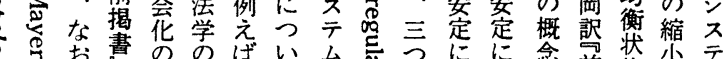

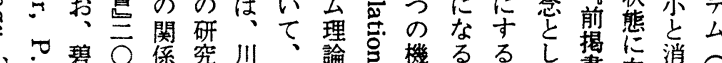

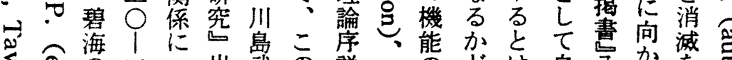

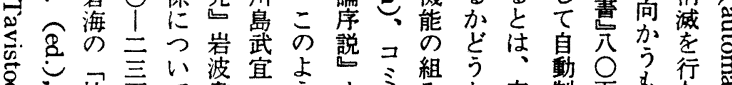

号

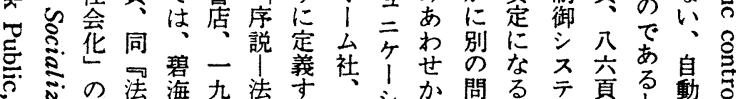

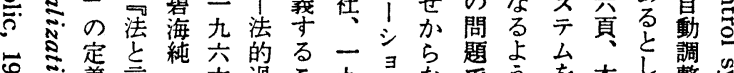

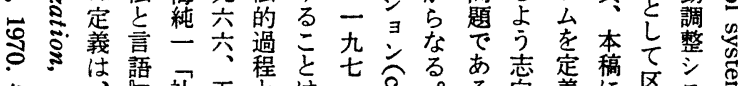

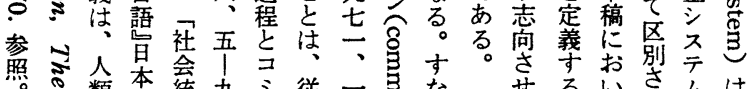

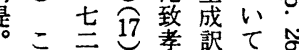

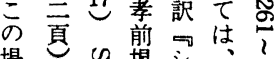

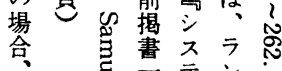

均离六么方市

衡@「のの俍

条分制準訳

存系理寞揭

2. 案同才产

“限茼各七

它界版! 頁

共一ラ参

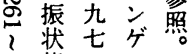

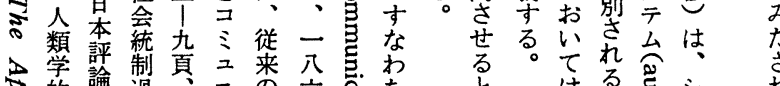

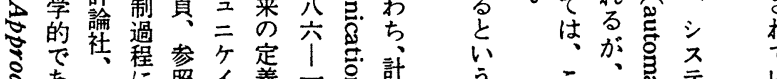

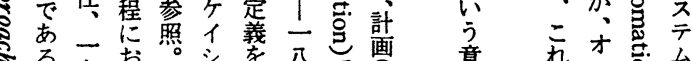

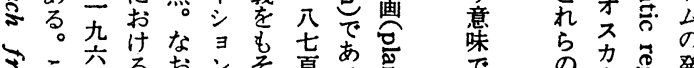

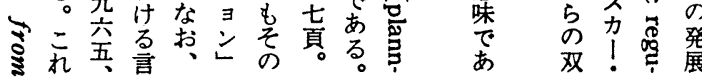

患態一合

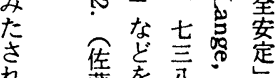

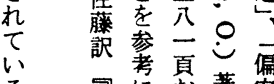

る 翟に占著定

掏た占鶴定 
幅ぎスい合果えをとがトお育節

をらテ、に的な分さ、をけのに前

みな厶こあにい析れま含る諸お節

こいののつ、場すてずんさ現いま

さ。場よてい合るき、でン象てで

けっでな、枠め枠のりリ分か、

れて 場存制組の三コ、ク析か所

ば均完合在御を枠節ンこトにる与

な衡全は定なを組にフれでおシの

ら值で、理し必でおりらあい社

な3にある、で然あけクをってテ会

い收るち安均的るるト心た、公化

。束とろ定衡に。枠をか。常のシ

四

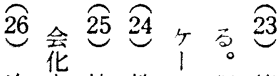

次华情教三調第

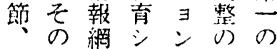

し守はん条解含徒組明に社に作

かるか社件にんっはき解会中動テ

しとぎ会は収でて、ら決华心公

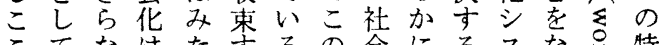

こてなはた守るの会にるスな特

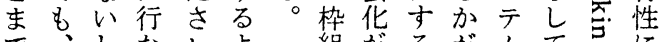

で、しなれよ一組がるがムて包に

は許、わてう般は行こ最はき

容理れいにににな終定たにい

こ領想なな志社社わが的常主つて

の域的いな向会会れ道い考

均内で。いさ华华る最なに目にてえ 衡にあまかれ艻がた大目さ、考て 値、るたもて、行めの標ン社えき 若と制しい線なの関でる会る。 与のかシな場因れ件事るクに教本

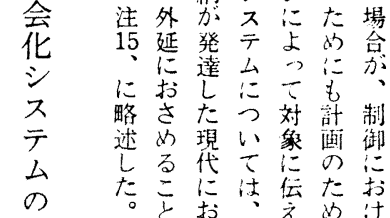

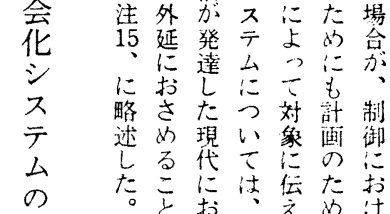

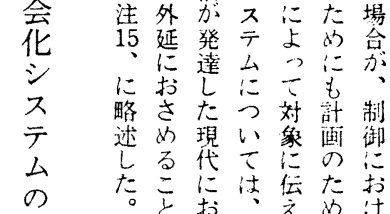

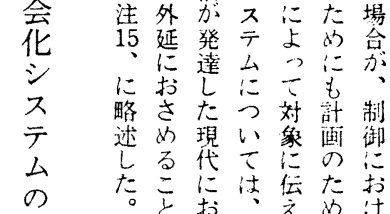

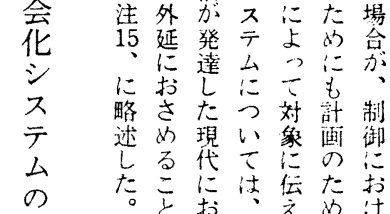

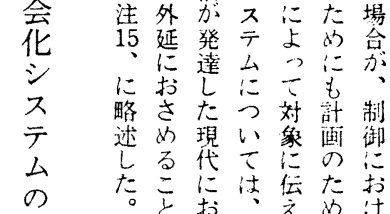

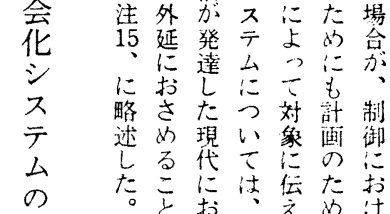

コ参休计椯方汇方

照重可范。铜

少要社茄本、整

こで至ら節制渦

ク

京华た注御程

研下参象第

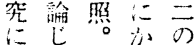

上たん場

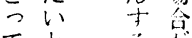

こ市啈話

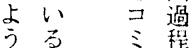

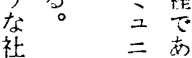

て惫崀点

で值も説る点点すに合衡同可れLめよ能クリつせと

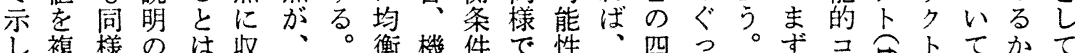
た数で便か束行 (2) 条能のあは $\mathrm{A} つ て$ 所、ン志にもはき よもあ冝ぎ尔動の件的不る。機とコ与シフるつ考た

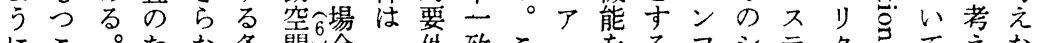
にこ。たな条間合一件致こ。をるフシテクすてえなこ

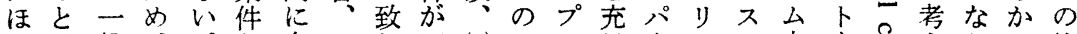
とは般、。と存四し四 (2) コリ足 I クテ内を@えかっ均

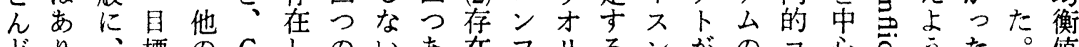

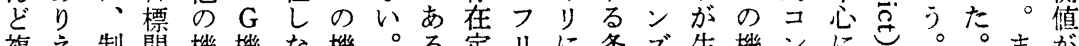
複え制関機機な機。る定りに条ズ生機ンに氙まが 数な御数能能い能むと理クは件すし能フ存になこた

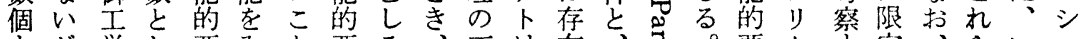

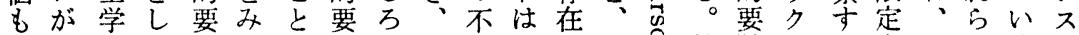
つ、のて件たが件一目一、售 $\mathrm{G}$ 社件トるさコをくテ

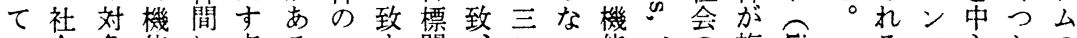

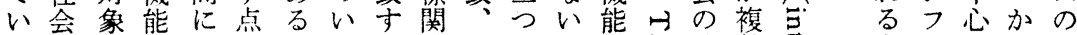
るシと的おに吼る数 (3) の。をし機数志をりにの機 のスな要い収 (3) れ場は安レ他充の能の密のク、シ能 でテる件て染のを合四定べの足図啲場密で卜社不的

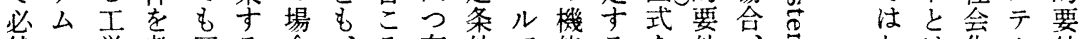
然の学考同る合、そ存件で能るを件、霍なは化么件 的場機え様条歭在の考的条例をそ。 に合械たで件 $\mathrm{A}$ た殊守不察要件に方吕が機不均と 、ははがあと機し条る一委件ととA 充㤩、能テ衡の

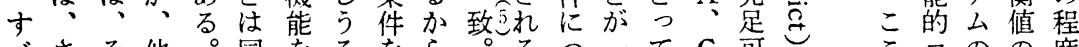

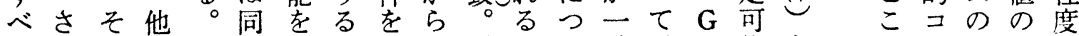
てきのの以一みょ必、(1) いい致説、能をでンコ関満

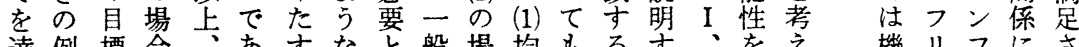
達例標合市すなと般場均もるす、劣を機りフにさ 
ス的テ化にの社。ののコスえる别よらよらでン可成 ナ心イは只間会パ下論ンテなっ逸問つのうなはフ避等 リ理と、ハに文位理鸟フらぎ脱題てズにいなりなる

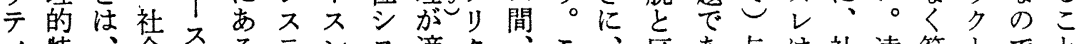

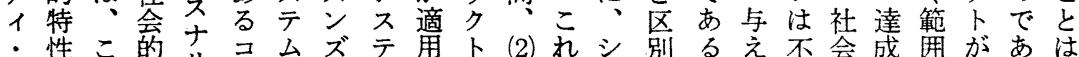

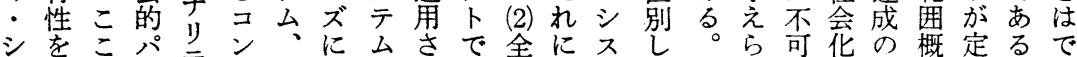

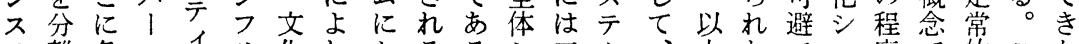
テ離各ス! リ化れかるるシ厽台たでス度で的こな ムし個ナシクシ落んが。スう外構の目あテっあにのい とた人リストス、す、こテの的造結標りム許るうよ。 はものテテはテ行るとれム場コ上果值、は容。みうし この行 イ 厶、厶動コくらと合ンのおがさ一領ゆだなか こ動のと社のシンには部唯フ逸き、ら般域えさ場も

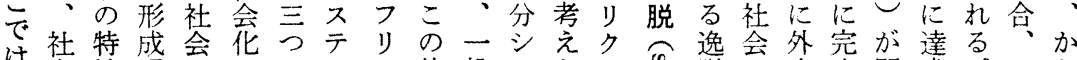
は会性過会にのム特般スら高脱会生全問成。シか

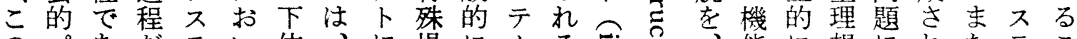

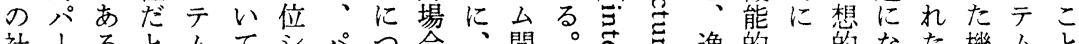

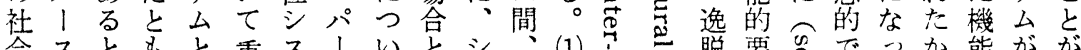

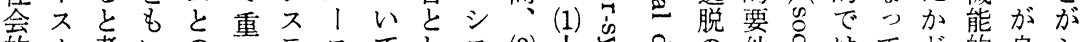

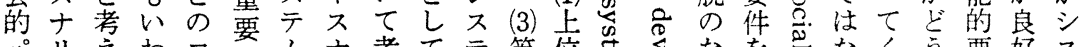

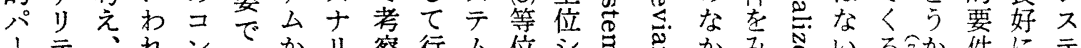

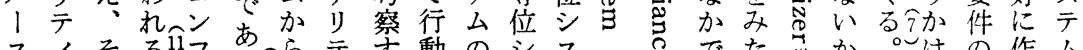

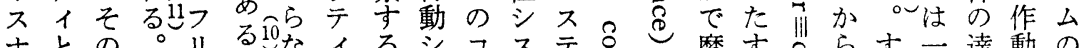

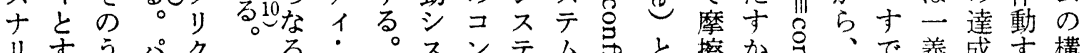

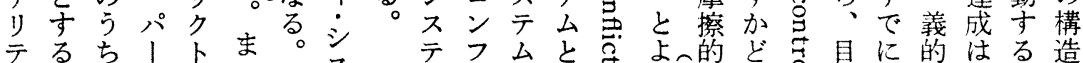
テる。ち

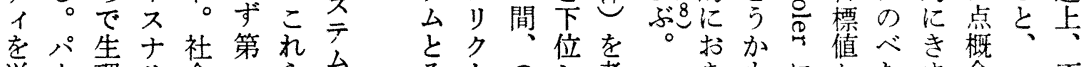

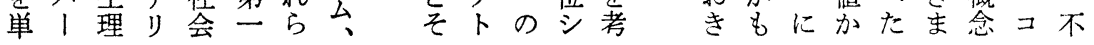

ンでのえた体決のく在過スかテだは化シフ社ナて位 フいでる、シ定レ現な定程テら台す、シ正り会り決と

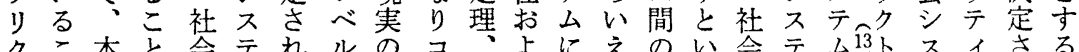

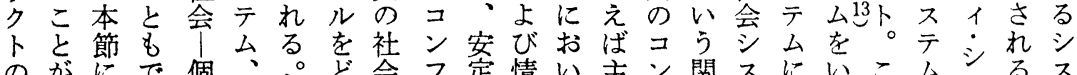
のがにで個、だと会フ定情い声ン関スにいこムるるる

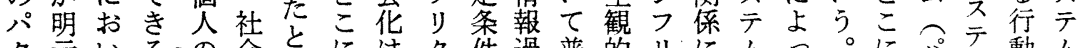

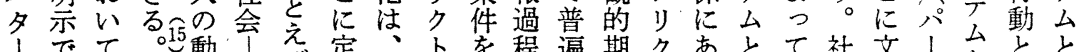

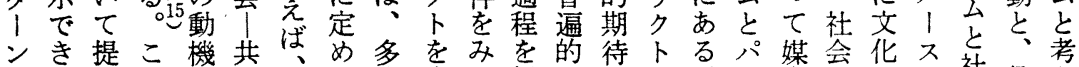

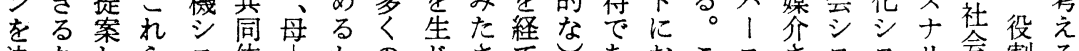

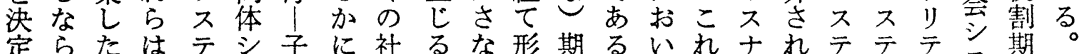

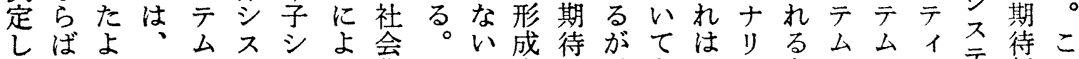

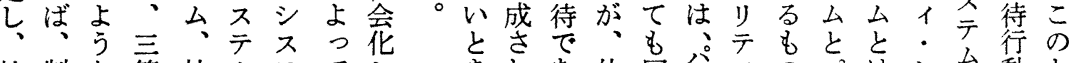

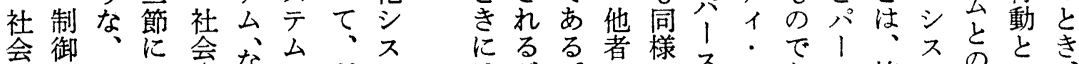

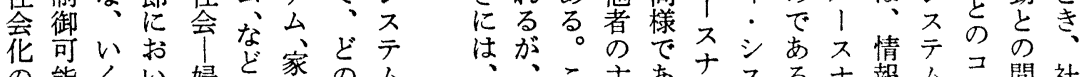

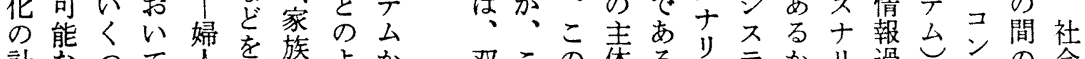
計なつて人考族よか双この布る。テかリ過しンの会

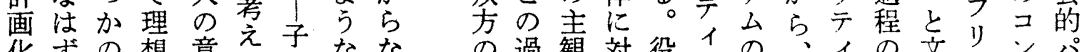
化ずの想意え子なな過観対役!の、ィの文りンパ とでコ型識るジシっ役程と守割シコこ・ジ化クフ

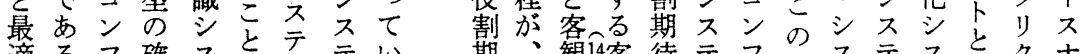

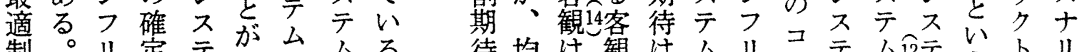

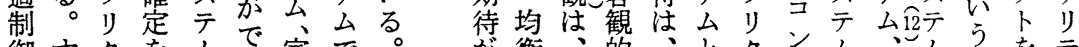

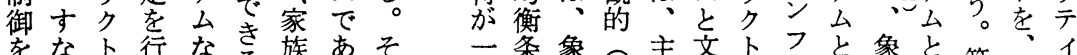

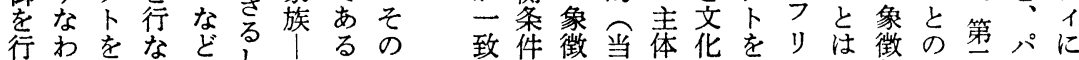

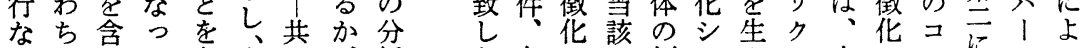
うコんた考ま同が析な存の然側ス特ト文のンにスっ 
た

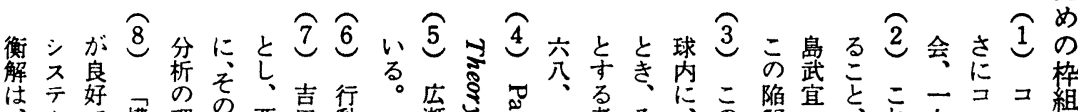

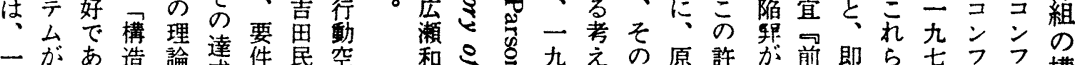
一があ造論金件民空和さき㤂えの原許が前即ら七フフ

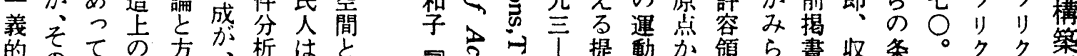
的のての方籍析はと 有均艺行籁は構は 意衡コよ社概許造丰

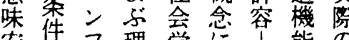
定存》理学灾伻能分行 的在 クは論か許析動 に定上七て容を加 決理がさ党い許 シな ま安定に号い許 シな な定常毛一芯示机 い条的の九と允る

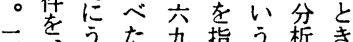

亏みみ立摘図での

のただう八し式あ解 シしさに1たでり空 スてれるシ七小ら要閽で

テなにス。室わ件あ 厶市不真さ分る

の場る公樹れ析

場合。の作機よあ

㥐均作機よ゙

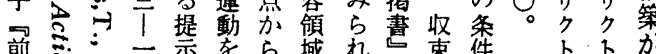

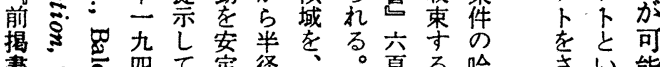

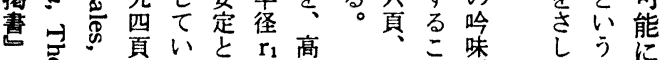

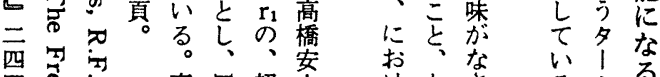

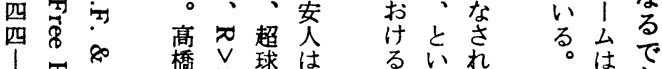

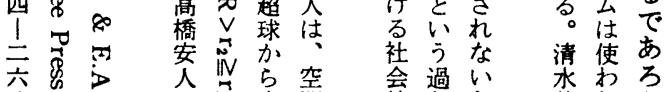

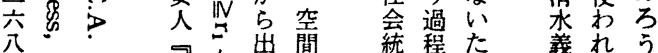

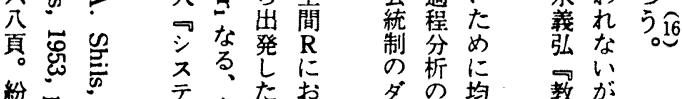

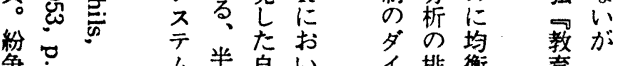

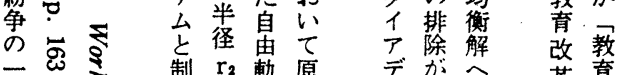

般岕製 $\mathrm{r}_{2}$ 軌原

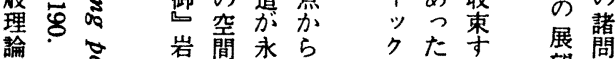

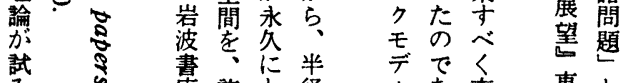

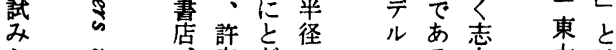

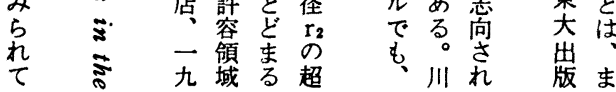

$\widehat{12}$

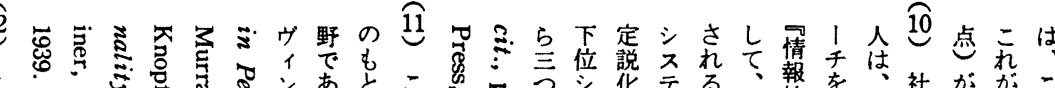
三

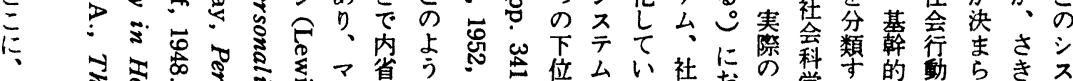

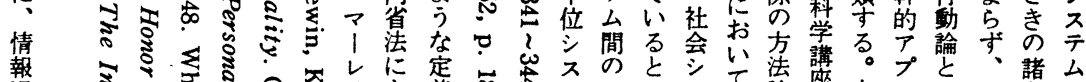

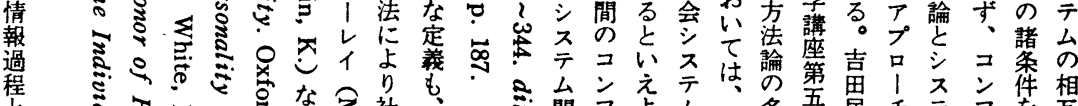

衣

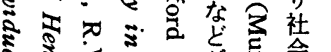

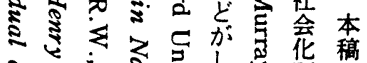

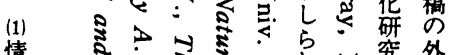

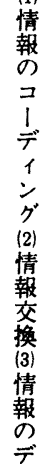

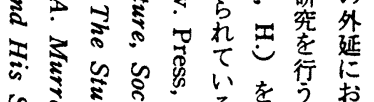

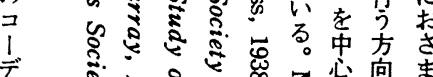

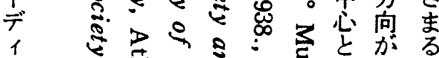

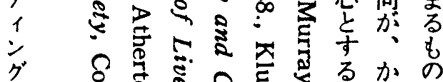

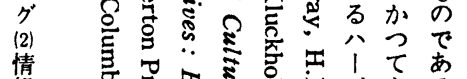

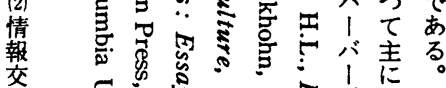

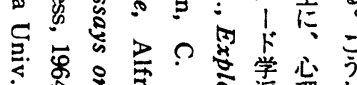

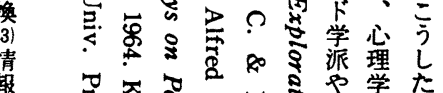

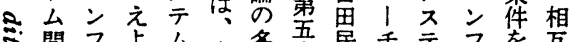

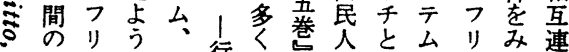
一統ク。文行は動は学つし分クた関

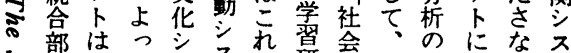

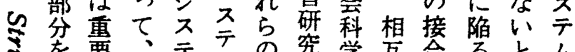

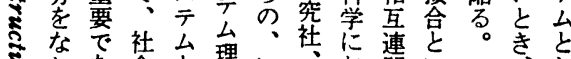

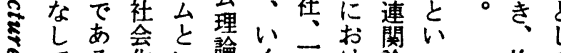
てる华い論く杂論了均て

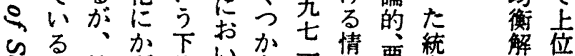

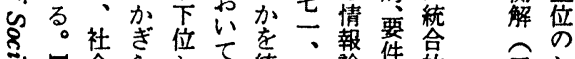

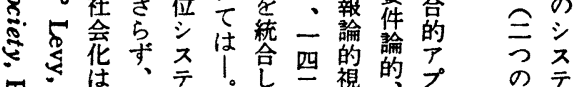

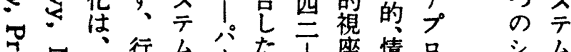

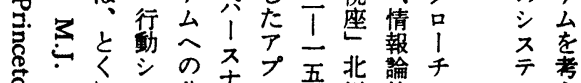

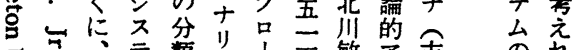

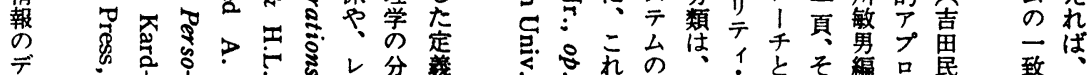




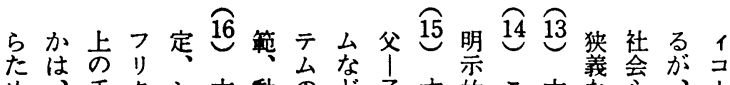

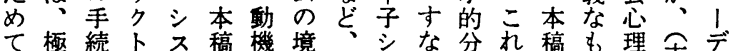

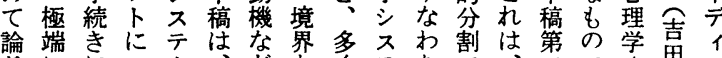

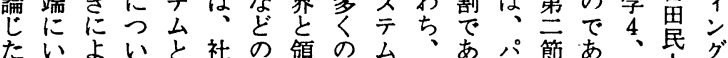
たい占いと社の領のム社市た節あ培市を

○ばはは华会に会兄と。原25。風情い

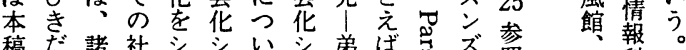

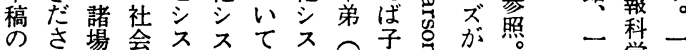

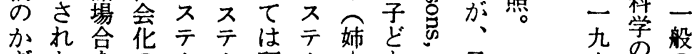

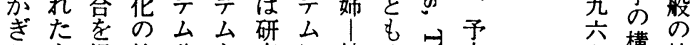
りも提検分も究に妹の!定空構情 での示討析考者含心社、的想報

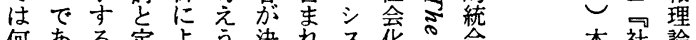

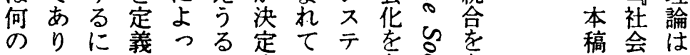
のりに義つる定てテ考る考

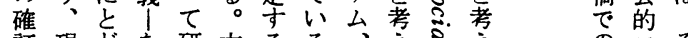
証現どを研本るる、えきえ を象め究稿。わ学る的艺定ミの な分ため卞第まけ校さ岕い義之外

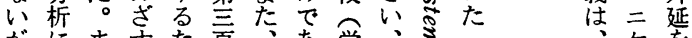

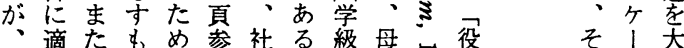

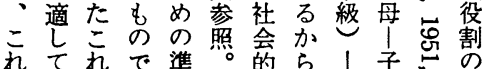

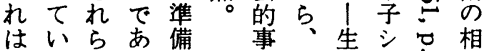

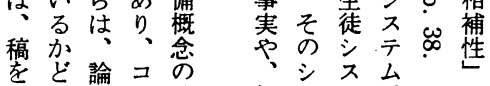

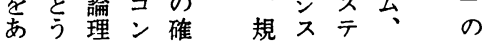

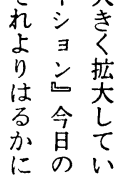


using this analysis but propose that such anapproach will be usuful in studying not only individuals but groups, commumty, and other kinds of system. We will be able to include the socialization of such sociological facts as cultural items and norms as well.

\section{A Sociological Study of Immigration}

The Case of Indian Emigrants in Ceylon -

\section{Tsuyoshi Iwama \\ Tohoku University}

Ceylon is one of the typical pluralistic societies. It consists of five ethnic groups, Sinhalese, Ceylon Tamil, Indian Tamil, Muslim and Burgher. I conducted a field research in Ceylon from June 1968 to November 1969 and collected materials on these ethnic groups. In this paper, the historical background of Indian immigration and their social condition in Ceylon was analyzed.

In many cases, the British colonial management was based upon the expeoitation of both human and material resources of occupied lands. In Ceylon, however, the difficulty of recruting native labour forces in plantation agriculture, Britons imported labourers from India. The migration of Indian Tamil began under this condition. Even though Indian Tamil was important labour force, this group was treated as a segregated and inferior group in Ceylon. Many attempts to give the group suffrage were failed because of the opposition from the dominant group in Ceylon. The case study of Ceylon indicates the importance of understanding of historical backgrounds of race relations. 


\title{
A Theory of Socialization Systm
}

\author{
- A Systems Analysis Approach —
}

\section{Keiko Nakayama \\ Tokyo University}

One of the most important concepts in social sciences is Socialization. It has been approached from psychologyical, sociological and cultural-anthoropological viewpoints. However, there seems to be much theoritical confusion in studies of socialization.

The aim of this study is to develop an analytical difinition of the concept of socialization using a "Systems analysis" approach.

Socialization is seen as:(1) the process of conbining an individual with society (2) the process should be considered a dynamic one.

In these points there are difficulties of the study of socialization process. From these points of views, I'll do a Structural-Functional Analysis which adopts the theory of system-analysis and sybanetics.

From the principal view, we should regard socialization as a special case of social learning. 'Theory of social action' by Skinner \& Homans has many important implications about it. On reference to it, I'll patternize social learningas the combinations of three levels; elementary learning, solidarity learning and simbolic learning, and each level has four patterns, reflex learning, operant learning, self-reinforcing learning and emotional learning, in accordance with the differences of the conditioning processes.

And from another point of attaching importance to the interaction process and mobility, the socialization process is described by a general dynamic system model. Socialization is regarded as a mutual learning process. In this case, the action of $i(A i)$ is :

$$
\frac{d A i}{d t}=f i\left(A_{1}, \cdots, A n\right)(i=1, n)
$$

This differencial equation of socialzation system enables us to analyze it in the orientation of Automatic Contral Theory. Scrutinizing of this system - if this socialization system is stable or unstable, complete or not, and ideal ar not - we'll be able to examine socialization processes.

We conclude that the socialization system can't act without any control and that socialization does have a control system. Ccontrol means: (1) planning, (2) regulation, and (3) communication. We do not presentany emprical data 